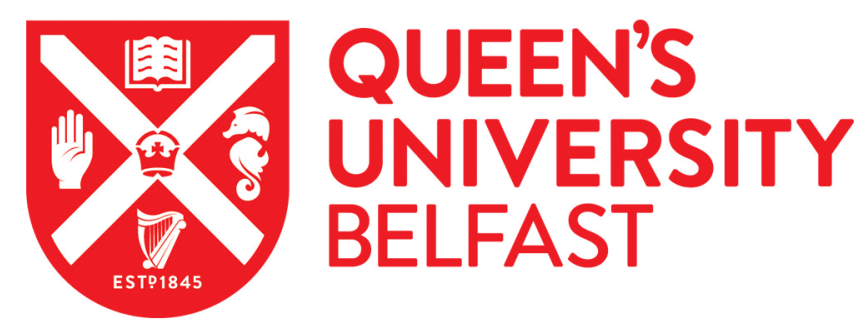

\title{
The effect of individual and mixtures of mycotoxins and persistent organochloride pesticides on oestrogen receptor transcriptional activation using in vitro reporter gene assays
}

Eze, U. A., Huntriss, J., Routledge, M. N., Gong, Y. Y., \& Connolly, L. (2019). The effect of individual and mixtures of mycotoxins and persistent organochloride pesticides on oestrogen receptor transcriptional activation using in vitro reporter gene assays. Food and Chemical Toxicology, 130, 68-78.

https://doi.org/10.1016/j.fct.2019.05.014

Published in:

Food and Chemical Toxicology

Document Version:

Peer reviewed version

Queen's University Belfast - Research Portal:

Link to publication record in Queen's University Belfast Research Portal

Publisher rights

(c) 2019 Published by Elsevier Ltd.

This manuscript version is made available under the CC-BY-NC-ND 4.0 license http://creativecommons.org/licenses/by-nc-nd/4.0/,which permits distribution and reproduction for non-commercial purposes, provided the author and source are cited.

\section{General rights}

Copyright for the publications made accessible via the Queen's University Belfast Research Portal is retained by the author(s) and / or other copyright owners and it is a condition of accessing these publications that users recognise and abide by the legal requirements associated with these rights.

\section{Take down policy}

The Research Portal is Queen's institutional repository that provides access to Queen's research output. Every effort has been made to ensure that content in the Research Portal does not infringe any person's rights, or applicable UK laws. If you discover content in the

Research Portal that you believe breaches copyright or violates any law, please contact openaccess@qub.ac.uk. 
The effect of individual and mixtures of mycotoxins and persistent organochloride pesticides on oestrogen receptor transcriptional activation using in vitro reporter gene assays

Ukpai A. Eze $^{\text {a, b, } \psi}$, John D. Huntriss ${ }^{c}$, Michael N. Routledge ${ }^{d}$, Yun Yun Gong ${ }^{\text {a, }}{ }^{*}$ and Lisa Connolly ${ }^{\mathrm{f}}$

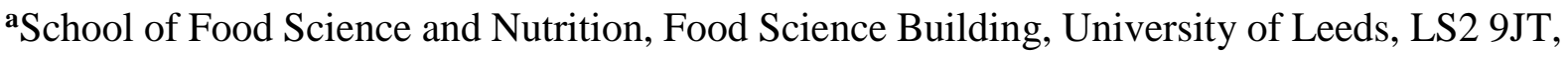
UK

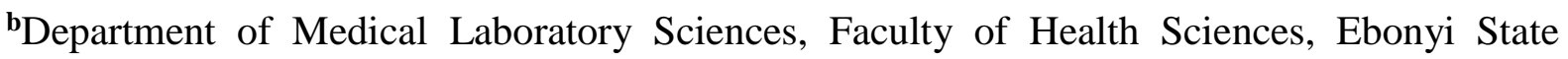
University, P. M. B. 053, Abakaliki, Nigeria

'Division of Reproduction and Early Development, Leeds Institute of Cardiovascular and Metabolic Medicine, School of Medicine, University of Leeds, LS2 9JT, UK

dLeeds Institute of Cardiovascular and Metabolic Medicine, School of Medicine, University of Leeds, LS2 9JT, UK

eDepartment of Food Safety Risk Assessment, China National Center for Food Safety Risk Assessment, Ministry of Health, Beijing, 100021 PR China

fInstitute for Global Food Security, School of Biological Sciences, Queens University Belfast, Northern Ireland, BT9 5AF, UK

*Corresponding Author (reprints):

\section{Yun Yun Gong PhD}

School of Food Science and Nutrition, Food Science Building,

University of Leeds, Leeds, LS2 9JT, United Kingdom.

Tel: +44 (0) 1133431415; E-mail: y.gong@ leeds.ac.uk

${ }^{\psi}$ Current address: School of Life Sciences, Faculty of Health and Life Sciences, Coventry University, CV1 2DS, United Kingdom (E-mail: ad2179@ coventry.ac.uk) 


\begin{abstract}
The mycotoxins zearalenone (ZEN) and alpha-zearalenone ( $\alpha-Z \mathrm{Z})$, which are common contaminants of agri-food products, are known for their oestrogenic potential. In addition to mycotoxins, food may also contain pesticides with oestrogenic properties such as 1,1,1trichloro-2,2-bis(p-chlorophenyl) ethane ( $p, p^{\prime}$-DDT) and 1,1-dichloro-2,2-bis( $p$-chlorophenyl) ethylene ( $p, p^{\prime}$-DDE), raising the question on the potential effects of individual and combinations of these xeno-oestrogens on the action of natural oestrogens. The present study employed a mammalian reporter gene assay to assess the effects individual and binary combinations of these environmental and food-borne contaminants on oestrogen nuclear receptor (ER) transactivation. As expected, $\alpha-\mathrm{ZOL}$ and ZEN exhibited the strongest oestrogenic potency $\left(\mathrm{EC}_{50}: 0.27 \pm 0.121 \mathrm{nM}\right.$ and $1.32 \pm 0.0956 \mathrm{nM}$, respectively) whereas $p, p^{\prime}-$ DDT and $p, p^{\prime}$-DDE had weak ER agonistic activity with the maximal response of $28.70 \pm$ $2.97 \%$ and $18.65 \pm 1.77 \%$, respectively. Concurrent treatment of the mycotoxins and/or pesticides, individually or in binary combination, with $17 \beta$-oestradiol $\left(\mathrm{E}_{2}\right)$ showed either additive, synergistic or antagonistic interactive effects on $\mathrm{E}_{2}$-mediated $\mathrm{ER}$ response, depending on the combination ratios, the concentration range of xeno-oestrogens, and the concentration of $E_{2}$. This study highlights the importance of assessing the mixture effects of chemical contaminants in risk assessment, especially in the area of reproductive and developmental toxicity.
\end{abstract}

Keywords: Mycotoxins; Chemical mixtures; Food-borne chemical contaminants; Reporter gene assay; Endocrine disruptor; Reproductive and developmental toxicity 


\section{Introduction}

Oestrogen $\left(\mathrm{E}_{2}\right)$ plays an important role in cell growth, differentiation, and the proper functioning of both the male and female reproductive systems (Kuiper et al., 1998). This critical biological function of oestrogen is mediated through the oestrogen receptors (ER); ESR1 (ER $\alpha)$ and ESR2 (ER $\beta)$, which are members of the nuclear receptor superfamily. There has been increasing evidence that many natural chemicals in food and synthetic environmental chemicals have the ability to interfere with the ER activity in both humans and animals resulting in endocrine disruption (Connolly, 2009). A few natural toxins in food (e.g. mycotoxins) and some synthetic chemicals (e.g. pesticides) are known to possess oestrogenic and/or anti-oestrogenic properties, and cause adverse reproductive health outcome in humans and animals, including precocious puberty and early thelarche in females, poor sperm quality, modified sexual behaviour, and alteration of the functions of reproductive organs in males and females (Diamanti-Kandarakis et al., 2009; Massart et al., 2008, 2010; Connolly et al., 2011; Bittner et al., 2014; Kowalska et al., 2016). Zearalenone (ZEN) and its metabolites alphazearalenol ( $\alpha$-ZOL) and beta-zearalenol ( $\beta$-ZOL) also exhibited endocrine disrupting effects at the level of nuclear receptor signalling and steroidogenesis using in vitro bioassays (Frizzell et al., 2011). There is the possibility of ZEN, $\alpha-Z O L$ and $\beta-Z O L$ occurring in mixtures in biological systems as they are produced simultaneously by Fusarium species in corn stems (Minervini and Dell'Aquila, 2008) and can be found in edible tissues of farm animals (Dänicke and Winkler, 2015). Furthermore, as pesticides especially $p, p^{\prime}$-DDT and $p, p^{\prime}$-DDE are common contaminants of the environment and agricultural produce, co-occurrence with mycotoxins is inevitable (Romero-González et al., 2011; Akoto et al., 2013). 
Research into the effects of mycotoxins, including ZEN, $\alpha$-ZOL and $\beta-Z O L$ on ER transcriptional activity has traditionally focused on the effects of single toxins (Kuiper et al., 1998; Shier et al., 2001; Frizzell et al., 2011; Cozzini et al., 2012; Molina-Molina et al., 2014; Ehrlich et al., 2015; Drzymala et al., 2015) while only a few studies have assessed the effects mixtures of these toxins may have on ER transcriptional activity (Demaegdt et al., 2016; Vejdovszky et al., 2017a, 2017b). However, multiple mycotoxin exposure is the rule and not the exception. For instance, the examination of 7049 feed and feedstuff from the Americas, Europe and Asia collected between 2009 and 2011 found that $48 \%$ had two or more mycotoxins, including aflatoxin $\mathrm{B}_{1}\left(\mathrm{AFB}_{1}\right)$, deoxynivalenol (DON), $\mathrm{ZEN}$ and ochratoxin $\mathrm{A}$ (OTA) (Rodrigues and Naehrer, 2012). In a subsequent study, feed, millet, maize and infant foods collected from Burkina Faso and Mozambique contained multi-mycotoxins (Warth et al., 2012). In addition, human exposure to multiple mycotoxins have been reported in several epidemiological studies using multi-mycotoxin biomarker method (Shephard et al., 2013; Warth et al. 2013). Multi-mycotoxin exposure poses a global public health threat as animal and in vitro studies have shown that additive, synergistic or antagonistic effects occur in mycotoxin mixtures (Alassane-Kpembi et al., 2013; Greiner and Oswald, 2011), highlighting the necessity of evaluating the health effects of mycotoxin co-occurrence.

It is well established that ZEN, $\alpha-\mathrm{ZOL}$ and $\beta$-ZOL activate $\mathrm{ER} \alpha$ and $\mathrm{ER} \beta$ both in vitro and in vivo, with $\alpha$-ZOL showing the highest oestrogenic potency (EFSA, 2016, 2017; Tatay et al., 2018). The estrogenic potential of dichlorodiphenyltrichloroethane (DDT) and its isomers have also been investigated with 1,1,1-trichloro-2,2-bis(p-chlorophenyl) ethane ( $p, p^{\prime}$-DDT) and 1,1dichloro-2,2-bis ( $p$-chlorophenyl) ethylene ( $p, p^{\prime}$-DDE) showing low agonistic activities on ERs whereas $o, p^{\prime}$-DDT (1,1,1-trichloro-2(p-chlorophenyl)-2-(o-chlorophenyl) ethane) had strong oestrogenic activity (Chen et al., 1997; Brennan et al., 2016). However, there are no reports on 
the effect of binary combinations of ZEN, $\alpha-Z O L$ and either other mycotoxins or DDT on $\mathrm{E}_{2}$ mediated ER transcriptional activation. Therefore, the present study evaluated the effect of individual and mixtures of mycotoxins and/or persistent organochloride pesticides on ER nuclear transcriptional response in the absence or presence of $E_{2}$ (the endogenous ER agonist which will naturally vary in concentration) using the MMV-Luc reporter gene assay (MMVLuc RGA).

\section{Materials and methods}

\subsection{Mycotoxins and chemicals}

Zearalenone (ZEN; purity $\geq 98 \%$ ), alpha-zearalenol ( $\alpha$-ZOL; purity $\geq 98 \%$ ), Deoxynivalenol (DON; purity $\geq 98 \%$ ), ochratoxin A (OTA; purity $\geq 98 \%$ ), 1,1,1-trichloro-2,2-bis(pchlorophenyl) ethane ( $p, p^{\prime}$-DDT; purity $\geq 98 \%$ ), 1,1-dichloro-2,2-bis(p-chlorophenyl) ethylene (p,p'-DDE; purity $\geq 98 \%)$, methanol (99.99\%), 17ß-estradiol $\left(\mathrm{E}_{2}\right)$, fulvestrant (ICI 182,780; purity $\geq 98 \%$ ), progesterone ( $\mathrm{P}_{4}$; purity $\geq 99 \%$ ), sterile Dulbecco's phosphate buffered saline (PBS) and charcoal-stripped foetal bovine serum were purchased from Sigma-Aldrich (Dorset, England). The cell proliferation kit I (Cat. No: 11465007001) containing 3-[4,5dimethylthiazol-2-yl]-2,5-dipenyltetrazolium bromide labeling reagent (MTT; $5 \mathrm{mg} / \mathrm{mL}$ in PBS) and solubilisation solution (10\% Sodium dodecyl sulphate in $0.01 \mathrm{M}$ hydrochloric acid) were obtained from Roche Diagnostics (Mannheim, Germany). Dulbeco’s Modified Eagle Medium (DMEM) without phenol red, TrypLE ${ }^{\mathrm{TM}}$ Express, Countess ${ }^{\mathrm{TM}}$ cell counting chamber slides and trypan blue were obtained from Invitrogen ${ }^{\mathrm{TM}}$ Life Technologies (Paisley, UK). All other chemicals used were standard laboratory grade. The stock concentrations of mycotoxins, hormones and fulvestrant were made in methanol and the final concentration of methanol in the culture medium was $0.5 \%(\mathrm{v} / \mathrm{v})$ equivalent to the highest methanol concentration of 
working dilutions. This was tested and results were not significantly different from media controls.

\subsection{Reporter Gene Assay}

The stably transfected MMV-Luc reporter gene cell line was a kind gift from Dr Marc Muller (University of Liège, Liège, Belgium) and was previously developed from the human mammary MCF-7 cell line (ATCC HTB-22) by transformation with a luciferase reporter construct under the control of an oestrogen inducible promoter, the MAR-Vit-Luc reporter plasmid (Willemsen et al., 2004). It is specific for the detection of oestrogen receptor transcriptional activation and endogenously expresses both alpha and beta oestrogen receptor, but predominantly alpha. The oestrogen-responsive element (ERE) construct vit-gpt was a gift from Gerhart U. Ryffel (Universitätsklinikum Essen, Essen, Germany) and previously cloned from Xenopus vitellogenin A2 (vit. A2) gene (Klein-Hitpass et al., 1988). Briefly, the pLuc reporter vector was developed through the insertion of a $2.0 \mathrm{~Kb}$ XhoI/StyI fragment from $\mathrm{pXP} 2$ containing the luciferase gene and the SV40 polyadenylation signal, into the promoterless pBLCAT6 vector opened by XhoI/StyI (Willemsen et al., 2004). Thereafter, the HindIII fragment of the Xenopus A2 vitellogenin promoter was isolated from Vit-gpt vector (KleinHitpass et al., 1988) and inserted into the HindIII-opened pLuc vector. This resulted in the generation of the Vit-Luc firefly luciferase reporter construct. Furthermore, a HindIII/EcoRI (800 bp) fragment containing a nuclear scaffold-attached region sequence was inserted into the StuI site upstream of the Vit promoter to generate a stably integrated MAR-Vit-Luc vector (Willemsen et al., 2004). Then, a MCF-7 human breast cancer cell line (ATCC HTB-22) which expresses both ER- $\alpha$ and ER- $\beta$ receptors (Al-Bader et al., 2011) was transformed with the MAR-Vit-Luc reporter plasmid to obtain the MMV-Luc cell clone (Willemsen et al., 2004). 
The oestrogenic response obtained from the mammalian-based ER reporter gene cell lines has been shown to be well correlated with the response observed using the gold standard for oestrogenic assay 'in vivo uterotrophic assay in immature or ovarietomised rodents' (Wang et al., 2014a,b), providing faster, easier and cheaper alternative testing strategy for oestrogenicity.

\subsubsection{Cell culture}

MMV-Luc cells were cultured in DMEM (without phenol red) containing $10 \%$ charcoalstripped foetal bovine serum without antibiotics and maintained in a $75 \mathrm{~cm}^{2}$ cell culture flask (Nunc, Roskilde, Denmark) at $37{ }^{\circ} \mathrm{C}$ in a humidified atmosphere $(95 \%)$ with $5 \% \mathrm{CO}_{2}$ for at least $48 \mathrm{~h}$ before use to ensure that the cells are completely free from hormonal induction from the media. For experiments, attached cells were liberated from flasks using TrypLE ${ }^{\mathrm{TM}}$ Express trypsin (Invitrogen ${ }^{\mathrm{TM}}$ Life Technologies, Paisley, UK), counted for viability checks prior to seeding plates by trypan blue staining and using a Countess ${ }^{\circledR}$ automated cell counter (Invitrogen ${ }^{\mathrm{TM}}$ Life Technologies, Paisley, UK). Cells $(100 \mu \mathrm{L})$ were seeded at a density of $4 \mathrm{x}$ $10^{5}$ cells/mL into each well of white walled 96-well plates with clear flat bottoms (Greiner BioOne, Frickenhausen, Germany) and incubated for 24 hours to allow cells to attach before chemical treatment.

\subsubsection{Effects of individual mycotoxins and pesticides on ER transcriptional response}

The cells $\left(4 \times 10^{5}\right.$ cells/mL per well) were exposed to different concentrations of mycotoxins, persistent organochloride pesticides, reference hormones and fulvestrant (ICI 182,780; ER antagonist) diluted with media to the final concentrations: ZEN $(0.01-1000 \mathrm{nM}), \alpha-\mathrm{ZOL}$ (0.005 - $50 \mathrm{nM})$, DON $(1-30,000 \mathrm{nM})$, OTA $(1-30,000 \mathrm{nM}), p, p^{\prime}$-DDT $(1.0-50.0 \mu \mathrm{M})$, $p, p^{\prime}$-DDE $(1.0-50.0 \mu \mathrm{M}), \mathrm{E}_{2}(0.0005-10 \mathrm{nM})$, fulvestrant (ICI 182,780; $\left.1 \mu \mathrm{M}\right)$, progesterone 
(500 nM), and methanol (0.5\%) and media controls. The MMV-Luc reporter gene assay was performed as previously reported (Frizzell et al., 2011; Ndossi et al., 2012), except that cells were treated with chemicals diluted with media without antibiotics and were incubated for 48 $\mathrm{h}$ instead of $24 \mathrm{~h}$. The presence of antibiotics in media causes high background luciferase response (Wilson et al., 2004). After incubation for 48 hours, the media supernatants were discarded, the cells washed once with sterile PBS and lysed with $25 \mu \mathrm{L}$ of lysis buffer (Promega, Southampton, UK; Cat. No.: E1531). Finally, $100 \mu \mathrm{L}$ of luciferase enzyme (Promega, Southampton, UK; Cat. No.: E1501) was injected into each well and the luciferase activity in relative light units (RLUs) were measured using the Mithras LB 940 Multimode luminometer (Berthold, Other, Germany). The luminescence readings of each treatment was normalised to the readings of $\mathrm{E}_{2}$ alone $(10 \mathrm{nM})$ and this was taken as the maximum response $(100 \%)$. Vehicle $(0.5 \%$ methanol) controls were used to define the minimum response $(0 \%)$. This gave the relative response of the cell line to each compound was calculated and compared with activity of $0.5 \%$ methanol and $\mathrm{E}_{2}(10 \mathrm{nM})$ arbitrarily set at $0 \%$ and $100 \%$, respectively. Measurements of $10 \mathrm{nM} \mathrm{E}, 0.5 \%$ methanol and progesterone were conducted in parallel on every single plate and served as positive, solvent and negative controls, respectively.

\subsubsection{Effects of individual and mixtures of mycotoxins and pesticides on $E_{2}$-meduated ER} response

The mycotoxins (ZEN and $\alpha$-ZOL) and pesticides ( $p, p^{\prime}$-DDT and $p, p^{\prime}$-DDE) with relative estrogenic response above $10 \%$ were selected and tested together with $\mathrm{E}_{2}(0.05 \mathrm{nM}$ and $10 \mathrm{nM})$ either in single or binary combinations to ascertain their additive and antagonistic and effects on $\mathrm{E}_{2}-$ mediated ER transcriptional response. The $0.05 \mathrm{nM}$ and $10 \mathrm{nM}$ of $\mathrm{E}_{2}$ were chosen as they fall within the reference ranges of serum concentrations of $E_{2}$ seen in females in pre- 
pubertal stage, during puberty and in late pregnancy (JECFA; 2000; Elmlinger et al., 2002). The normal serum $\mathrm{E}_{2}$ concentration is usually in the range $8-18 \mathrm{pg} / \mathrm{mL}(0.029-0.066 \mathrm{nM})$ in prepubertal women, $20-350 \mathrm{pg} / \mathrm{mL}(0.073-0.35 \mathrm{nM})$ in premenopausal women and this reaches peak level (18,000 pg/mL: $66.1 \mathrm{nM})$ in late pregnancy (JECFA; 2000; Elmlinger et al., 2002). Furthermore, circulating $\mathrm{E}_{2}$ level ranges $\leq 10-50 \mathrm{pg} / \mathrm{mL}(0.037-0.184 \mathrm{nM})$ both in prepubertal and adult men, depending on age (JECFA; 2000). Serum concentration of ZEN $(0.628-1.492 \mu \mathrm{M}), \alpha-$ ZOL $(0.218-2.207 \mu \mathrm{M})$ and $\beta$-ZOL $(0.343-2.207 \mu \mathrm{M})$ have been reported in individuals with breast and cervical cancer (Pillay et al., 2002), and this is similar to those used in this study. In addition, serum $p, p^{\prime}$-DDT and $p, p^{\prime}$-DDE concentrations of 40.311 $\mu \mathrm{M}$ and $86.155 \mu \mathrm{M}$, respectively have been reported in human exposure studies (Dua et al., 2001; Longnecker et al., 2002).

The concentrations of ZEN (0.01 nM - $1000 \mathrm{nM}), \alpha-Z O L(0.005 \mathrm{nM}-50 \mathrm{nM}), p, p^{\prime}$-DDT (1 $\mu \mathrm{M}-50 \mu \mathrm{M})$ and $p, p^{\prime}-\mathrm{DDE}(1 \mu \mathrm{M}-50 \mu \mathrm{M})$ were used in single or binary combinations tested together with the selected concentrations of $E_{2}$. After exposure of the cells to the mycotoxins and pesticides together with $\mathrm{E}_{2}(0.05 \mathrm{nM}$ and $10 \mathrm{nM})$ either in single or binary combinations for 48 hours, the media supernatants were discarded, the cells washed once with PBS and lysed with $25 \mu \mathrm{L}$ of lysis buffer (Promega, Southampton, UK). Finally, $100 \mu \mathrm{L}$ of luciferase enzyme (Promega, Southampton, UK) was injected into each well and the luciferase activity in relative light units (RLU's) were measured using the Mithras Multimode Reader (Berthold, Other, Germany). The relative response of the cell line to each compound was calculated and compared with activity of $0.5 \%$ methanol and $\mathrm{E}_{2}(0.05 \mathrm{nM}$ and $10 \mathrm{nM})$ arbitrarily set at $100 \%$. Measurements of $\mathrm{E}_{2}(0.05 \mathrm{nM}$ and $10 \mathrm{nM}), 0.5 \%$ methanol and progesterone were conducted in parallel on every single plate and served as positive, solvent and negative controls, respectively. The high affinity ER antagonist ICI 182,780 was used to verify whether the 
detected estrogenic responses are ER dependent. $\mathrm{E}_{2}(0.05 \mathrm{nM}$ and $10 \mathrm{nM})$ was co-incubated with $1 \mu \mathrm{M}$ of ICI 182,780 and the inhibition of oestrogenic response of $\mathrm{E}_{2}$ confirmed that the responses observed in the assay were mediated oestrogen receptors (ERs). Progesterone was tested in each plate as a negative control and it had no estrogenic response.

\subsection{Cell viability and cytotoxicity assay}

The MMV-Luc cells were seeded and treated as described for reporter gene assay (RGA). After 48 hours of treatment, $20 \mu \mathrm{L}$ of MTT labeling reagent $(5 \mathrm{mg} / \mathrm{mL})$ was added into each well containing cells growing in $200 \mu \mathrm{L}$ of medium and plates covered with aluminum foil. The plates were incubated for 4 hours at $37{ }^{\circ} \mathrm{C}$ in a humidified atmosphere (95\%) with $5 \% \mathrm{CO}_{2}$. Thereafter, $100 \mu \mathrm{L}$ of solubilisation solution (10\% SDS in $0.01 \mathrm{M} \mathrm{HCl}$ ) was added to each well and incubated overnight at $37{ }^{\circ} \mathrm{C}$ in a humidified atmosphere $(95 \%)$ with $5 \% \mathrm{CO}_{2}$. The plates were then read at $570 \mathrm{~nm}$ with a reference wavelength of $690 \mathrm{~nm}$ with TECAN Safire2 (TECAN, Switzerland) microtitre plate reader. Viability of the each test sample was calculated as the percentage $(\%)$ absorbance when compared with the absorbance of the $0.5 \%$ methanol vehicle control.

\subsection{Statistical analysis}

Both RGA and MTT assay exposures were carried out in triplicate wells and in three independent experiments. Results were expressed as the mean \pm standard deviation (Mean \pm SD) of the triplicate exposures. For the RGAs, relative dose response (fold induction) was calculated from the relative light units (RLUs) when compared with the negative control ( $n$ fold) using Microsoft Excel (Microsoft, Redmond, Washington) and normalised with the response of $E_{2}(10 \mathrm{nM})$ arbitrarily set at $100 \%$. The dose-response curves were fitted with 
GraphPad PRISM software version 5.0 (San Diego, CA) using the sigmoidal dose-response curve equation, $Y=$ Bottom $+($ Top - Bottom $) /\left(1+10^{(\mathrm{EC} 50-\mathrm{X})}\right)$, where $X$ is the logarithm of concentration, $Y$ (the response), and Bottom and Top are set at $0 \%$ and $100 \%$ for the lowest and maximal transcriptional response of the assay. A one way analysis of variance (ANOVA) and Dunnett's multiple comparison test was used to determine significant differences between the treatments and the corresponding controls in the RGAs and MTT assays. The mean concentrations were tested for significant difference at the $95 \%$ confidence level. A $p$ value of $<0.05$ was considered statistically significant, $p \leq 0.05(*), \leq 0.01(* *), \leq 0.001(* * *)$ and $\leq$ $0.0001(* * * *)$. The half maximal effective concentration $\left(\mathrm{EC}_{50}\right)$ for the single compounds were determined by fitting dose-response curves using GraphPad PRISM version 6.0.

The interactive effects of the combined toxins on $\mathrm{E}_{2}$-mediated ER transcriptional response were calculated as previously described by Weber et al. (2005) and Clarke et al. (2014) and briefly shown below.

\section{Mean ER response of binary mixtures (expected in \% of substance 1 + substance 2)}

$=$ mean ER response (substance 1 in \%) + mean ER response (substance 2 in \%) maximal ER response by $10 \mathrm{nM}$ of E2 (100\%).

The standard deviation (SD) was calculated using the model described by Weber et al. (2005) as shown below:

Expected SD $($ substance $1+$ substance 2$)=\left[(\mathrm{SD} \text { of substance } 1)^{2}+(\mathrm{SD}\right.$ of substance $\left.2)^{2}\right]^{1 / 2}$

In order to evaluate the interactive effects of the combined toxins below or above additivity, expected additive values were compared to actually measured values using a multiple t-test and corrected for multiple comparison using Holm-Š́ídák test method, with $\mathrm{p}<0.05$.

The results were interpreted as follows:

- Additive effects: measured ER response values were not significantly above or below the expected values. 
- Synergistic effects: measured ER response values were significantly below expected values.

- Antagonistic effects: measured ER response values were significantly above expected values.

\section{Results}

\subsection{Cell viability and cytotoxicity}

The single mycotoxins, pesticides and $\mathrm{E}_{2}$ did not reduce the cell viability of MMV-Luc cell line after $48 \mathrm{~h}$ in all the concentrations tested (Supplementary file 1). It was found that ZEN and $\mathrm{E}_{2}$ significantly increased cell proliferation $(\mathrm{p} \leq 0.001)$ whereas $\alpha-Z O L$ slightly increased cell proliferation at $1 \mu \mathrm{M}$ and $50 \mu \mathrm{M}(\mathrm{p} \leq 0.05)$. In the concurrent exposure of either single or binary mixtures of mycotoxins and pesticides with $\mathrm{E}_{2}$ at $0.05 \mathrm{nM}$ and $10 \mathrm{nM}$, no cytotoxic effect was observed (Supplementary file 1) indicating that the transcriptional responses observed are not as a result of reduced cell viability.

3.2 ER transcriptional response induced by single mycotoxins and persistent organochloride pesticides

The maximum induction of the $\mathrm{E}_{2}(10 \mathrm{nM})$ standard in MMV-Luc reporter gene assay (RGA) was set at $100 \%$ in determining the transcriptional response of the other environmental and food-borne contaminants. Therefore, the response from other compounds is relative to this maximal response by $10 \mathrm{nM}$ of $\mathrm{E}_{2}$. The dose-response curve for the $\mathrm{ER}$ transcriptional activation of the single mycotoxins and pesticides is shown in Figure 1. Among the single compounds tested, $\mathrm{E}_{2}$ at $1.0 \mathrm{nM}$ activated ER transcriptional response closely to the maximum induction $(95.93 \pm 3.92 \%)$ (Table 1.1). The highest transcriptional activation for ZEN was at 
$1 \mu \mathrm{M}(80.11 \pm 5.58 \%)$ whereas its major metabolite $\alpha-\mathrm{ZOL}$ at $50 \mathrm{nM}$ induced similar response $(73.45 \pm 3.25 \%)\left(\right.$ Table 1.1). A dose response curve was plotted (Table 1.1), $\mathrm{E}_{2}$ had an $\mathrm{EC}_{50}$ of $0.053 \pm 0.012 \mathrm{nM}$ while ZEN and $\alpha-Z O L$ had $\mathrm{EC}_{50}$ of $1.32 \pm 0.10 \mathrm{nM}$ and $0.27 \pm 0.12$ $\mathrm{nM}$, respectively. In this study, $p, p^{\prime}$-DDT and $p, p^{\prime}$-DDE also weakly activated ER transcription with the highest response occurring at $50 \mu \mathrm{M}, 28.70 \pm 2.97 \%$ and $18.65 \pm 1.77 \%$, respectively (Table 1.1).

3.3 Effects of single mycotoxins and persistent organochloride pesticides on $E_{2}$-mediated ER transcriptional response

It was observed that co-incubation of either ZEN or $\alpha-Z O L$ with $E_{2}(0.05 \mathrm{nM})$ significantly $(\mathrm{p}$ $\leq 0.001$ ) modulated the ER transcriptional response induced by $\mathrm{E}_{2}$, alone (Fig. 2A \& 2C) with more induction occurring at lower doses $(0.01 \mu \mathrm{M}-2.5 \mu \mathrm{M})$ in each case. On the contrary, coincubation of the same doses of either ZEN or $\alpha-\mathrm{ZOL}$ with $10 \mathrm{nM}$ of $\mathrm{E}_{2}$ caused a dosedependent inhibition of ER response (Fig. 2B \& 2D) reducing $E_{2}$-mediated response by approximately $40 \%$ at $10 \mu \mathrm{M}$, in each case. Concurrent treatment of MMV-Luc cells with $p, p^{\prime}-$ DDT or $p, p^{\prime}$-DDE with $\mathrm{E}_{2}(0.05 \mathrm{nM}$ or $10 \mathrm{nM})$ significantly reduced the ER transcription activation caused by $\mathrm{E}_{2}$, alone (Fig. $\mathbf{2 E}-\mathbf{2 H}$ ).

3.4 Effects of binary mixtures of mycotoxins and persistent organochloride pesticides on $E_{2}$ mediated ER transcriptional response

Co-treatment of ZEN $+\alpha-\mathrm{ZOL}, \mathrm{ZEN}+p, p^{\prime}-\mathrm{DDT}$, or ZEN $+p, p^{\prime}$-DDE with $\mathrm{E}_{2}(0.05 \mathrm{nM})$ significantly $(\mathrm{p} \leq 0.001)$ enhanced the transcriptional response induced by E2 alone at lower concentrations whereas little or no effects were observed at higher concentrations (Fig. 3A, 3C \& 3E; Supplementary Fig. S2.1). In contrast, co-exposure of $\mathrm{E}_{2}(10 \mathrm{nM})$ with $\mathrm{ZEN}+\alpha-\mathrm{ZOL}$, $\mathrm{ZEN}+p, p^{\prime}$-DDT, or ZEN + p, $p^{\prime}$-DDE significantly decreased the E2-mediated ER response 
dose-dependently $(\mathrm{p} \leq 0.001)$, with the highest doses combinations reducing ER transcriptional response to approximately 40\% (Fig. 3B, 3D \& 3F; Supplementary Fig. S2.1).

This study also tested the ER transcriptional activation that will be elicited by concurrent exposure of $\mathrm{E}_{2}(0.05 \mathrm{nM}$ or $10 \mathrm{nM})$ with different dose combinations of $\alpha-\mathrm{ZOL}+p, p^{\prime}$-DDT, $\alpha-\mathrm{ZOL}+p, p^{\prime}-\mathrm{DDE}$ or $p, p^{\prime}-\mathrm{DDT}+p, p^{\prime}-\mathrm{DDE}(\mathbf{F i g} .4)$. It was noted that $\alpha-\mathrm{ZOL}+p, p^{\prime}-\mathrm{DDT}$ and $\alpha-\mathrm{ZOL}+p, p^{\prime}$-DDE significantly $(\mathrm{p} \leq 0.001)$ modulated the transcriptional response of $\mathrm{E}_{2}$ at $0.05 \mathrm{nM}$, but strongly inhibited the ER response mediated by E2 $(10 \mathrm{nM})$ with the highest dose combinations ( $\alpha$-ZOL: $10 \mu \mathrm{M} ; p, p^{\prime}$-DDT: $50 \mu \mathrm{M}$ and $p, p^{\prime}$-DDE: $\left.50 \mu \mathrm{M}\right)$ reducing $\mathrm{E}_{2}$-mediated ER transactivation response by over 70\% (Fig. 4A - 4D; Supplementary Fig. S2.2). Cotreatment of equimolar mixtures of $p, p^{\prime}$-DDT and $p, p^{\prime}$-DDE with $\mathrm{E}_{2}$ at $0.05 \mathrm{nM}$ or $10 \mathrm{nM}$ caused a dose-dependent decrease in $\mathrm{E}_{2}$-mediated ER transactivation response and this was completely inhibited at equimolar concentrations $(40 \mu \mathrm{M}$ and $50 \mu \mathrm{M})$ for $0.05 \mathrm{nM}$ of $\mathrm{E}_{2}$ cotreatment and at $50 \mu \mathrm{M}$ for $10 \mathrm{nM}$ of $\mathrm{E}_{2}$ (Fig. 4E \& 4F; Supplementary Fig. S2.2).

\section{Discussion}

There has been an increasing concern that environmental and dietary chemicals cause endocrine disruption leading to potential adverse effects on both animal and human reproduction (Diamanti-Kandarakis et al., 2009). In this study, the MMV-Luc cell line expressing both ER- $\alpha$ and ER- $\beta$ receptors was employed to determine the effects of single and mixtures of mycotoxins and/or persistent organochloride pesticides on oestrogen receptor transcriptional activity. Since human reproductive organs such as testis, prostate, ovary, premenopausal and foetal uteri, and endometrium contain significant amounts of both ER- $\alpha$ and ER- $\beta$ receptors (Mosselman et al. 1996; Brandenberger et al., 1997, 1998, 1999), and given the 
critical role that ER- $\beta$ plays in modulating the functional activity and levels of ER- $\alpha$, the use of reporter cell lines with one ER subtype (ER- $\alpha$ or ER- $\beta$ ) may underestimate the overall estrogenic potency of a sample (Brennan et al., 2016). This is true as oestrogenic chemicals that were not detected using BG1Luc4E2 cells expressing only ER- $\alpha$ were identified by the BG1LucER $\beta$ c9 cells which constitutively expresses both ER- $\alpha$ and ER- $\beta$ (Brennan et al., 2016). In addition, ER transcriptional response mediated by $p, p$ '-DDT, heptachlor, lindane, endrin, tedion, thiodan, methoxychlor and $o, p^{\prime}$-DDT were higher in reporter cells with both ER- $\alpha$ and ER- $\beta$ compared to ER $\alpha$-containing reporter cells, indicating the modulation of the expression of ER- $\alpha$ target genes by ER- $\beta$ or ER- $\beta$-specific gene induction (Bardin et al., 2004) and therefore, the use of reporter cells expressing only ER- $\alpha$ or ER- $\beta$ but not both may underestimate the overall potency of (anti-)oestrogenic compounds and/or mixtures (Brennan et al., 2016).

\subsection{Transcriptional activation of ER by single mycotoxins and persistent organochloride} pesticides

Among the single compounds tested, $\mathrm{E}_{2}$ at $1.0 \mathrm{nM}$ and $10.0 \mathrm{nM}$ activated ER transcriptional response by approximately $95.93 \pm 3.92 \%$ and $100 \%$ induction, respectively. ZEN induced approximately $80.11 \pm 5.58 \%$ ER transcriptional response at $1 \mu \mathrm{M}$ whereas its major metabolite $\alpha$-ZOL induced approximately $73.45 \pm 3.25 \%$ ER transcriptional response at $50 \mathrm{nM}$, relative to the response exhibited by $10 \mathrm{nM} \mathrm{E}_{2}(100 \%)$. This is in agreement with the result of Ehrlich et al. (2015) who reported that ZEN and its metabolites $(0.05 \mathrm{pM}-0.5 \mu \mathrm{M})$ induced maximum ER transcriptional response of $60-75 \%$ in human oestrogen receptor-chemically activated luciferase expression (hER-CALUX) assay. However, in human 293 embryonal kidney (HEK) cells expressing luciferase (Luc) and $\beta$-galactosidase (LacZ), the transcriptional 
response of ZEN on $\mathrm{ER} \alpha$ and $\mathrm{ER} \beta$ at $1 \mu \mathrm{M}$ was $91 \%$ and $27 \%$, respectively (Kuiper et al., 1998). The $\mathrm{EC}_{50}$ values of each compound were measured from a dose response curve and was used as a representative of oestrogenic potency. In this study, $\mathrm{E}_{2}$ strongly induced oestrogenic response with an $\mathrm{EC}_{50}$ value of $0.053 \pm 0.012 \mathrm{nM}$ which is similar to most previously reported $\mathrm{EC}_{50}$ values of $\mathrm{E}_{2}$ using different assay methods (Jobling et al., 1995; Balaguer et al., 1996; Sonneveld et al., 2005; Brennan et al., 2016). However, this $\mathrm{EC}_{50}$ value of $\mathrm{E}_{2}(0.053 \pm 0.012$ nM) was slightly higher than the ones reported by Frizzell et al. (2011) and Demaegdt et al. (2016) using the same oestrogenic responsive (MMV-Luc) cell line. It is possible incubation of chemicals in cells for longer duration (e.g. 48 h) compared to shorter duration (e.g. 24 h) could affect their oestrogenic potency possibly due to metabolic capacity of cells. The comparison of the $\mathrm{EC}_{50}$ data of $\mathrm{ZEN}$ and its major metabolite $\alpha-\mathrm{ZOL}$ was also in agreement with previous studies with $\alpha$-ZOL showing an increased oestrogenic potency compared with the parent compound ZEN (Frizzell et al., 2011; Molina-Molina et al., 2014; Ehrlich et al., 2015; Drzymala et al., 2015; Demaegdt et al., 2016). Although the ranking of oestrogenicity of ZEN and $\alpha$-ZOL was similar to report of previous studies, the $\mathrm{EC}_{50}$ values (ZEN: $1.32 \pm 0.0956$ $\mathrm{nM}$ and $\alpha$-ZOL: $0.27 \pm 0.121 \mathrm{nM}$ ) varied from those reported by Frizzell et al. (2011) and Demaegdt et al. (2016) using the same reporter cell line. It has been shown that the use of antibiotics or antifungals in culture media contribute to high background levels of luciferase response in T47D-KBLuc reporter cell line (Wilson et al., 2004). This can also be corroborated by the work of Covaleda and co-workers which highlighted that the presence of tetracycline in assay media inhibited ER $\beta$ protein expression and modulated $\mathrm{E}_{2}$-induced cell proliferation compared to that observed in the absence of tetracycline (Sotoca Covaleda et al., 2008). One major drawback of using the ER reporter assay over the activation of endogenous ER gene targets is that the stability of the luciferase reporter gene transfected into the cells could affect their luciferase responsiveness (Wang et al., 2012). In addition, unstable transfection can lead 
to a loss of the luciferase reporter gene construct from the genome of the cells resulting in variations in absolute luminescence values. Interestingly, a stable transfection of the luciferase reporter gene occurred in the MMV-Luc cell line used in this study (Willemsen et al., 2004).

The organochloride pesticide $p, p^{\prime}$-DDT and major metabolite $p, p^{\prime}$-DDE showed weak oestrogenic response with the highest concentrations tested $(50 \mu \mathrm{M})$ showing response of 28.70 $\pm 2.97 \%$ and $18.65 \pm 1.77 \%$ relative to the maximal response induced by $\mathrm{E}_{2}(100 \%)$, respectively. It was noted that $p, p^{\prime}$-DDT significantly induced ER transcriptional response at 1 $\mu \mathrm{M}$ and above whereas significant response was only observed at $25 \mu \mathrm{M}$ for $p, p^{\prime}$-DDE. In a yeast-based reporter gene assay, $p, p^{\prime}$-DDT and $p, p^{\prime}$-DDE were ER agonists with $p, p^{\prime}$-DDT significantly inducing the $\beta$-galactosidase activity at concentration of $1 \mu \mathrm{M}$ and a $20 \%$ response $\left(\mathrm{EC}_{20}\right)$ found at $51 \mu \mathrm{M}$ (Li et al., 2008). In a more recent studies, $p, p^{\prime}$-DDT $(10 \mu \mathrm{M})$ induced an ER response of $19.0 \pm 5 \%$ in an ER $\alpha$ expressing reporter (BG1LUc4E2) cell line and $30 \pm 3 \%$ in a reporter cell line $\left(\mathrm{BG} 1 \mathrm{LucERB}_{\mathrm{C}} 9\right)$ expressing both ER $\alpha$ and $\mathrm{ER} \beta$ (Brennan et al., 2016), similar to the results of this study. However, $p, p^{\prime}$-DDE was a more potent agonist in a MELN reporter cell line with an $\mathrm{EC}_{50}$ of approximately $26 \mu \mathrm{M}$ (Pillon et al, 2005) whereas $p, p^{\prime}$-DDT only showed weak agonistic activity (7\%) in HEK cells expressing ER $\alpha$ with luciferase reporter (Kuiper et al., 1998). In this study, DON and OTA had no oestrogenic response, similar to other studies using the same reporter cell line (Ndossi et al., 2012; Frizzell et al., 2013).

Oestrogens are essential in many reproductive function and can influence the growth, differentiation, and function of many target tissues in the reproductive system, including uterus, vagina, ovary, testes, epididymis, and prostate (Kuiper et al., 1998). In humans, about 1-2\% of 
circulating $\mathrm{E}_{2}$ is unbound while $40 \%$ is bound to sex hormone-binding globulin (SHBG) and the remaining fraction to albumin (JECFA; 2000). Currently, it is not clear whether ZEN and its metabolites interact or bind to carrier proteins (e.g. SHBG and albumin) as exhibited by endogenous hormones. In in vitro studies, the binding capacity of ZEN on SHBG from humans and cold-water fish Arctic charr (Salvelinus alpinus) was poor and therefore, the concentrations applied in vitro could have greater access to ER binding sites which may induce more response in vivo compared to endogenous oestrogens (Metzler et al., 2010; Molina-Molina et al., 2014). In addition, ZEN is known to activate the human pregnane $\mathrm{X}$ receptor (PXR), constitutive androstane receptor (CAR), and aryl hydrocarbon receptor (AhR) in HepG2 hepatoma cells, indicating that it can also mediate its effect through other nuclear receptors (Ayed et al., 2001). Also worthy of note, it has been speculated that ZEN and its metabolites, especially $\alpha$-ZAL, $\alpha$ ZOL and $\beta$-ZAL may act as androgen receptor (AR) antagonists as their half maximal inhibitory concentration $\left(\mathrm{IC}_{50}\right)$ values were within the same range as reported for two wellknown androgen receptor antagonists vinclozolin and flutamide in various reporter gene assays (Molina-Molina et al., 2014; Stypula-Trebas et al., 2016). On the other hand, $p, p^{\prime}$-DDE bioaccumulates in lipophilic tissues which are released into the blood and breast milk posing infant health risk as a result of its action as both ER and AR antagonists (Kelce et al., 1995, 1997). Therefore, it is possible that co-exposure of these mycotoxins and pesticides could lead to additive or synergistic effects on $\mathrm{E}_{2}$-mediated ER activation.

\subsection{Interactive effects of single mycotoxins and pesticides on $E_{2}$-mediated ER transcriptional} activation

It was observed that co-treatment of ZEN or $\alpha$-ZOL with $0.05 \mathrm{nM}$ of $\mathrm{E}_{2}$ significantly enhanced $\mathrm{E}_{2}$-mediated ER response in MMV-Luc reporter cell line in all the doses tested. In a previous study using the same MMV-Luc reporter cell line, Wielogórska and co-workers (2015) showed 
that butyl 4-hydroxybenzoate (PB-Bu) and propyl 4-hydroxybenzoate (PB-Pr) which exhibited strong oestrogenic response also enhanced $\mathrm{E}_{2}$-mediated response when co-exposed with $0.005 \mathrm{nM}$ of $\mathrm{E}_{2}$ (PB-Bu: $584.0 \%$ and PB-Pr: 460.0\%). Also in agreement with the result of this study, several combinations of strong oestrogenic compounds ZEN and alternariol $(\mathrm{AOH})$ or $\alpha-\mathrm{ZOL}$ and $\mathrm{AOH}$, at several concentrations had synergistic interaction and enhanced Ishikawa cell alkaline phosphatase production which exceeded the maximum induction $(100 \%)$ reached by $1 \mathrm{nM}$ of E2 (Vejdovszky et al., 2017a). This current study also observed that combination of ZEN $(0.01-10 \mathrm{nM})$ and $\alpha-\mathrm{ZOL}(0.01-10 \mathrm{nM})$ with the concentration of $\mathrm{E}_{2}$ $(10 \mathrm{nM})$, which showed maximal effect on ER transcriptional activation, resulted in significant dose-dependent reduction of $\mathrm{E}_{2}$-mediated $\mathrm{ER}$ transcriptional response, indicating that combination of ZEN and $\alpha$-ZOL act as partial agonists and competes with $\mathrm{E}_{2}$ for ER. In a more recent study, Vejdovszky et al. (2017b) demonstrated that binary combinations of genistein with ZEN or $\mathrm{AOH}$ resulted in either synergism or antagonism in the alkaline phosphatase assay, depending on the combination ratios and the concentration range. They also posited that the nature of interactions between two strong oestrogenic compounds may depend on the concentration ratio of the substances in the mixture and also on the concentration range applied. Furthermore, Wielogórska et al. (2015) demonstrated that the ER agonist di- $n$-butyl phthalate (DBP) at concentration of $1 \mu \mathrm{M}$ had no significant effect the $\mathrm{E}_{2}$-induced ER transcriptional activation when combined with $\mathrm{E}_{2}$ at $0.1 \mathrm{nM}$, but exhibited antagonistic effect at $10 \mu \mathrm{M}$ and $100 \mu \mathrm{M}$, reducing transactivation by $23 \%$ and $75 \%$, respectively and this was not as a result of cytotoxic effect on cells.

Furthermore, ZEN has been shown to be a mixed agonist/antagonist of both both ER- $\alpha$ and ER- $\beta$ receptors (Kuiper et al., 1998; Mueller et al., 2004) whereas other phytoestrogens, including resveratrol, enterolactone, 6-hydroxy- enterolactone are mixed weak agonist/antagonist of the ER- $\alpha$ in diethylstilbestrol-induced, ER-mediated activity in Ishikawa- 
$\mathrm{hER} \alpha$ and Ishikawa-hER $\beta$ cells (Mueller et al., 2004). In addition, ZEN acted as an agonist for both ER- $\alpha$ and ER- $\beta$ receptors (an endocrine disruptor) at low doses, but had ER antagonistic activity at high doses (Mueller et al., 2004). Bowers et al. (2000) also reported that resveratrol had slight antagonistic properties on ER $\alpha$ but not ER $\beta$ depending on the ERE sequence. Partial ER-agonists enterolactone, 6-hydroxy-enterolactone acted as partial ER- $\alpha$ antagonists, reducing diethylstilbestrol mediated-ER transactivation by $20-40 \%$ (Mueller et al., 2004). Similar to the result of our study, the xenoestrogen resveratrol increased the diethylstilbestrolinduced transactivation of ER $\alpha$ and ER $\beta$ at low doses, but at high doses it inhibited activity of ER $\alpha$ and ER $\beta$ (Mueller et al., 2004). Therefore, mixtures of either ZEN or $\alpha-Z O L$ with $E_{2}$ $(0.05 \mathrm{nM})$ may be able to elicit a more potent oestrogenic or anti-oestrogenic response than initially anticipated, posing a greater risk to reproductive health.

This study also demonstrated that co-exposure of $p, p^{\prime}$-DDT or $p, p^{\prime}$-DDE (especially at $\geq 5 \mu \mathrm{M}$ ) with either $0.05 \mathrm{nM}$ or $10 \mathrm{nM}$ of $\mathrm{E}_{2}$ significantly reduced the $\mathrm{E}_{2}$-mediated $\mathrm{ER}$ transcriptional activity, indicating antagonistic effects (Fig. 4E \& 4F; Supplementary Fig. S2.2). In a yeastbased hER reporter gene assay, combination of low dose of $\mathrm{E}_{2}(0.3 \mathrm{nM})$ with low concentrations (40 nM - $1 \mu \mathrm{M})$ of $p, p^{\prime}$-DDT, $o, p^{\prime}$-DDT or $0, \mathrm{p}^{\prime}$-DDE caused dose-dependent increase in transcriptional response, but this was not significantly different from the sum of the separate responses observed in $0.3 \mathrm{nM}$ of $\mathrm{E}_{2}$ or DDT isomers, alone (Chen et al., 1997). In addition, co-treatment of the above DDT isomers at equimolar concentrations (40 $\mathrm{nM}$ and 80 $\mathrm{nM}$ ) produced additive transcriptional response in a concentration-dependent manner (Chen et al., 1997). The authors concluded that co-exposure of DDT isomers and metabolites with $\mathrm{E}_{2}$ or another DDT isomer and metabolite can have an additive effect on hER transcriptional activation. 


\subsection{Interactive effects of the mixtures of mycotoxins and pesticides on $E_{2}$-mediated ER transcriptional activation}

Since human beings and animals are not exposed to food and environmental oestrogenic chemicals alone, but in mixtures with other oestrogenic chemicals, this study also examined the effect of such mixtures on $\mathrm{E}_{2}$-induced hER transcriptional activity. It was observed that mixtures of ZEN and $\alpha$-ZOL, ZEN and $p, p^{\prime}$-DDT, ZEN and $p, p^{\prime}$-DDE, $\alpha$-ZOL and $p, p^{\prime}$-DDT, and $\alpha$-ZOL and $p, p^{\prime}$-DDE when co-treated with $\mathrm{E}_{2}(0.05 \mathrm{nM})$ enhanced $\mathrm{E}_{2}$-induced hER transcription at low dose combinations, but had additive or antagonistic effects at high dose combinations. However, the above mixtures caused dose-dependent reduction (antagonistic effects) on $\mathrm{E}_{2}$-induced $\mathrm{hER}$ transcription when co-exposed with $10 \mathrm{nM}$ of $\mathrm{E}_{2}$. It has also been demonstrated that co-treatment of low concentrations of oestrogen agonists 4-Nonylphenol, $o, p^{\prime}$-DDT, methoxychlor, chlordane, endosulfan and dieldrin at $200 \mathrm{nM}$ to $2 \mu \mathrm{M}$ with low dose of $\mathrm{E}_{2}(0.003 \mathrm{nM})$ in T47D-ER CALUX assay caused induction of transcriptional response which were significantly different from the response of the individual treatments (Legler et al., 1999), similar to the result of this study. These results indicate that oestrogenic chemicals may act synergistically or antagonistically depending on combination ratio or concentration and further research is warranted in the in vivo effects of mixtures of xeno-oestrogens.

A major observation of this study is that exposure of equimolar concentrations of $p, p^{\prime}$-DDT and $p, p^{\prime}$-DDE mixtures with either $0.005 \mathrm{nM}$ or $10 \mathrm{nM}$ of $\mathrm{E}_{2}$ significantly reduced transcriptional response in concentration-dependent fashion and this response was completely inhibited at equimolar combinations $(40$ and $50 \mu \mathrm{M})$ for $0.05 \mathrm{nM}$ of $\mathrm{E}_{2}$ or $50 \mu \mathrm{M}$ exposure with $10 \mathrm{nM}$ of $\mathrm{E}_{2}$. This observation was not as a result of cell cytotoxicity as there was either a significant increase in cell number or no effect on cell viability at these concentrations 
(Supplementary file 1). In agreement with this study, the $\beta$-galactosidase activity was completely abolished when $p, p^{\prime}$-DDT $(100 \mu \mathrm{M})$ and $p, p^{\prime}$-DDE $(100 \mu \mathrm{M})$ were combined with $0.2 \mathrm{nM}$ of $\mathrm{E}_{2}$ in a yeast-based hER reporter gene assay, but significantly increased progesterone-mediated PR transcriptional activation (Li et al., 2008). Interestingly, serum $p, p^{\prime}-$ DDT and $p, p^{\prime}$-DDE concentrations of $40.311 \mu \mathrm{M}$ and $86.155 \mu \mathrm{M}$, respectively have been reported in human epidemiological studies (Dua et al., 2001; Longnecker et al., 2002) indicating clinical relevance of the effects observed in this study.

In conclusion, this study shows that oestrogenic mycotoxins and persistent organochloride pesticides, individually or in combination, have biphasic effects on $\mathrm{E}_{2}$-mediated $\mathrm{ER}$ transcriptional response depending on the concentration of $E_{2}$ present as well as the concentration of each compound during co-exposure. Modulatory interaction effects were observed for low concentrations of ZEN $+\alpha$-ZOL, ZEN $+p, p^{\prime}$-DDT, and $\alpha$-ZOL $+p, p^{\prime}$-DDT mixtures when combined with physiologically relevant concentrations of $\mathrm{E}_{2}$ whereas antagonistic effects were observed at high dose combinations. Of greatest concern is the finding that mixtures of equimolar concentrations of $p, p^{\prime}$-DDT and $p, p^{\prime}$-DDE antagonised the ER transcriptional response mediated by physiologically relevant concentrations of $\mathrm{E}_{2}$ both in low and high concentrations, and that combinations at $50 \mu \mathrm{M}$ completely inhibited the $\mathrm{E}_{2}$ mediated response. This study demonstrates the importance of assessing the interactive effects of oestrogenic compounds, individually or in mixtures, with physiologically relevant concentrations of $\mathrm{E}_{2}$ during risk assessment. The mechanisms through which mycotoxins and persistent organochloride pesticides cause reproductive and developmental toxicity are not currently known in detail, but it is most likely that these compounds act through different mechanisms. Therefore, both in vitro and in vivo bioassays should be used in further research to understand these mechanistic pathways. 


\section{Abbreviations}

DON: Deoxynivalenol; OTA: ochratoxin A; $\alpha$-ZOL: alpha-zearalenol; $\beta$-ZOL: betazearalenol; $p, p^{\prime}$-DDT: 1,1,1-trichloro-2,2-bis(p-chlorophenyl) ethane; $p, p^{\prime}$-DDE: 1,1-dichloro2,2-bis(p-chlorophenyl) ethylene; $\quad o, p^{\prime}$-DDT: 1,1,1-trichloro-2(p-chlorophenyl)-2-(ochlorophenyl) ethane; EDCs: endocrine disrupting chemicals; PBS: Dulbecco's phosphate buffered saline; MTT: 3-[4,5-dimethylthiazol-2-yl]-2,5-dipenyltetrazolium bromide solution; SDS: sodium dodecyl sulfate; $\mathrm{HCl}$ : hydrochloric acid; DMEM/F-12: Dulbecco's Modified Eagle Medium/F-12 nutrient mixture; ANOVA: analysis of variance; DMSO: dimethyl sulfoxide; E2: oestradiol/17ß-oestradiol; RGA: Reporter gene assay; ER: oestrogen receptor; ESR1 $(\mathrm{ER} \alpha)$ : oestrogen receptors alpha; ESR1 $(\mathrm{ER} \alpha)$ : oestrogen receptors beta; ATCC: American type culture collection; CALUX: Chemically activated luciferase expression; DBP: di-n-butyl phthalate; PB-Bu: butyl 4-hydroxybenzoate; and PB-Pr: propyl 4-hydroxybenzoate

\section{Conflict of interest statement}

The authors declare that there are no conflict of interest.

\section{Acknowledgements}

We gratefully acknowledge the partial PhD scholarship funding awarded to U. A. Eze by the Ebonyi State Government of Nigeria. The authors also thank Dr Maeve Shannon of the Institute for Global Food Security in Queens University Belfast for the training and guidance during the laboratory experiments of this study.

\section{Appendix}


Supplementary file 1. Cell viability of MMV-Luc cell line exposed to different chemical treatments.

Supplementary file 2. The interactive effects of combined mycotoxins and/or persistent organochloride pesticides on $\mathrm{E}_{2}$-mediated ER transcriptional activation.

\section{References}

Akoto, O., Andoh, H., Darko, G., Eshun, K., Osei-Fosu, P., 2013. Health risk assessment of pesticides residue in maize and cowpea from Ejura, Ghana. Chemosphere 92(1), 67-73.

Alassane-Kpembi, I., Kolf-Clauw, M., Gauthier, T., Abrami, R., Abiola, F.A., Oswald, I.P., Puel, O., 2013. New insights into mycotoxin mixtures: The toxicity of low doses of Type B trichothecenes on intestinal epithelial cells is synergistic. Toxicol Appl Pharmacol. 272(1), 191-198.

Al-Bader, M., Ford, C., Al-Ayadhy, B. and Francis, I., 2011. Analysis of estrogen receptor isoforms and variants in breast cancer cell lines. Exp Ther Med. 2(3), 537-544.

Ayed, Y., Ayed-Boussema, I., Ouanes, Z., Bacha, H., 2011. In vitro and in vivo induction of chromosome aberrations by alpha-and beta-zearalenols: Comparison with zearalenone. Mutat Res Genet Toxicol Environ Mutagen. 726(1), 42-46.

Balaguer, P., Joyeux, A., Denison, M.S., Vincent, R., Gillesby, B.E., Zacharewski, T., 1996. Assessing the estrogenic and dioxin-like activities of chemicals and complex mixtures using in vitro recombinant receptor reporter gene assays. Can J Physiol Pharmacol. 74(2), 216-222.

Bardin, A., Boulle, N., Lazennec, G., Vignon, F. and Pujol, P., 2004. Loss of ER $\beta$ expression as a common step in estrogen-dependent tumor progression. Endocr.-Relat. Cancer 11(3), 537551.

Bittner, G.D., Denison, M.S., Yang, C.Z., Stoner, M.A., He, G., 2014. Chemicals having estrogenic activity can be released from some bisphenol a-free, hard and clear, thermoplastic resins. Environ. Health 13(1), 103.

Bowers, J.L., Tyulmenkov, V.V., Jernigan, S.C. and Klinge, C.M., 2000. Resveratrol acts as a mixed agonist/antagonist for estrogen receptors $\alpha$ and $\beta$. Endocrinology 141(10), 3657-3667.

Brandenberger, A.W., Tee, M.K., Lee, J.Y., Chao, V. and Jaffe, R.B., 1997. Tissue distribution of estrogen receptors alpha (ER- $\alpha)$ and beta $(E R-\beta)$ mRNA in the midgestational human fetus. J Clin Endocrinol Metab. 82(10), 3509-3512. 
Brandenberger, A.W., Tee, M.K. and Jaffe, R.B., 1998. Estrogen receptor alpha (ER- $\alpha$ ) and beta (ER- $\beta$ ) mRNAs in normal ovary, ovarian serous cystadenocarcinoma and ovarian cancer cell lines: down-regulation of ER- $\beta$ in neoplastic tissues. J Clin Endocrinol Metab. 83(3), 10251028 .

Brandenberger, A.W., Lebovic, D.I., Tee, M.K., Ryan, I.P., Tseng, J.F., Jaffe, R.B. and Taylor, R.N., 1999. Oestrogen receptor (ER)- $\alpha$ and ER- $\beta$ isoforms in normal endometrial and endometriosis-derived stromal cells. Mol Human Reprod. 5(7), 651-655.

Brennan, J.C., Bassal, A., He, G., Denison, M.S., 2016. Development of a recombinant human ovarian (BG1) cell line containing estrogen receptor $\alpha$ and $\beta$ for improved detection of estrogenic/antiestrogenic chemicals. Environ Toxicol Chem. 35(1), 91-100.

Chen, C.W., Hurd, C., Vorojeikina, D.P., Arnold, S.F., Notides, A.C., 1997. Transcriptional activation of the human estrogen receptor by DDT isomers and metabolites in yeast and MCF7 cells. Biochem Pharmacol. 53, 1161-1172.

Clarke, R., Connolly, L., Frizzell, C., Elliott, C.T., 2014. Cytotoxic assessment of the regulated, co-existing mycotoxins aflatoxin B1, fumonisin B1 and ochratoxin, in single, binary and tertiary mixtures. Toxicon $90,70-81$.

Connolly, L., 2009. Endocrine disrupting chemicals: origins, fates and transmission into the food chain. Endocrine Disrupting Chemicals in Food. Woodhead Publishing Ltd, Cambridge, England, pp.103-125.

Connolly, L., Ropstad, E., Verhaegen, S., 2011. In vitro bioassays for the study of endocrinedisrupting food additives and contaminants. Trends Anal Chem. 30, 227-238.

Cozzini, P., Dellafiora, L., 2012. In silico approach to evaluate molecular interaction between mycotoxins and the estrogen receptors ligand binding domain: a case study on zearalenone and its metabolites. Toxicol Lett. 214(1), 81-85.

Dänicke, S., Winkler, J., 2015. Invited review: Diagnosis of zearalenone (ZEN) exposure of farm animals and transfer of its residues into edible tissues (carry over). Food Chem Toxicol. 84, 225-249.

Demaegdt, H., Daminet, B., Evrard, A., Scippo, M.L., Muller, M., Pussemier, L., Callebaut, A., Vandermeiren, K., 2016. Endocrine activity of mycotoxins and mycotoxin mixtures. Food Chem Toxicol. 96, 107-116.

Diamanti-Kandarakis, E., Bourguignon, J.P., Giudice, L.C., Hauser, R., Prins, G.S., Soto, A.M., Zoeller, R.T., Gore, A.C., 2009. Endocrine-disrupting chemicals: an Endocrine Society scientific statement. Endocr Rev. 30(4), 293-342.

Drzymala, S.S., Binder, J., Brodehl, A., Penkert, M., Rosowski, M., Garbe, L.A., Koch, M., 2015. Estrogenicity of novel phase I and phase II metabolites of zearalenone and ciszearalenone. Toxicon 105, 10-12.

Dua V.K, Kumari R, Sharma V.P, Subbarao S.K., 2001. Organochlorine residues in human blood from Nainital (UP), India. Bull. Environ Contam Toxicol. 67, 42-45. 
Ehrlich, V.A., Dellafiora, L., Mollergues, J., Dall'Asta, C., Serrant, P., Marin-Kuan, M., Lo Piparo, E., Schilter, B., Cozzini, P., 2015. Hazard assessment through hybrid in vitro/in silico approach: The case of zearalenone. Altex 32(4), 275.

Elmlinger, M.W., Kühnel, W., Ranke, M.B., 2002. Reference ranges for serum concentrations of lutropin ( $\mathrm{LH})$, follitropin (FSH), estradiol (E2), prolactin, progesterone, sex hormonebinding globulin (SHBG), dehydroepiandrosterone sulfate (DHEAS), cortisol and ferritin in neonates, children and young adults. Clin Chem Lab Med. 40(11), 1151-1160.

European Food Safety Authority (EFSA) Panel on Contaminants in the Food Chain (CONTAM)., 2016. Appropriateness to set up a group health-based guideline value for zearalenone and its modified forms. EFSA Journal 14, 4425-4471. Doi: 10.2903/j.efsa.2016.4425

EFSA CONTAM Panel (European Food Safety Authority Panel on Contaminants in the Food Chain), Knutsen, H.K., Alexander, J., Barregård, L., Bignami, M., Brüschweiler, B., Ceccatelli, S., Cottrill, B., Dinovi, M., Edler, L., Grasl-Kraupp, B., Hogstrand, C., $\quad 2017 . \quad$ Scientific Opinion on the risks for animal health related to the presence of zearalenone and its modified forms in feed. EFSA Journal 15(7), 4851. https://doi.org/10.2903/j.efsa.2017.4851

Frizzell, C., Ndossi, D., Verhaegen, S., Dahl, E., Eriksen, G., Sørlie, M., Ropstad, E.,Muller, M., Elliott, C.T., Connolly, L., 2011. Endocrine disrupting effects of zearalenone, alpha- and beta-zearalenol at the level of nuclear receptor binding and steroidogenesis. Toxicol Lett. 206, 210-217.

Frizzell, C., Verhaegen, S., Ropstad, E., Elliott, C.T., Connolly, L., 2013. Endocrine disrupting effects of ochratoxin A at the level of nuclear receptor activation and steroidogenesis. Toxicol Lett. 217(3), 243-250.

Grenier, B., Oswald, I., 2011. Mycotoxin co-contamination of food and feed: meta-analysis of publications describing toxicological interactions. World Mycotoxin J. 4(3), 285-313.

Jobling, S., Reynolds, T., White, R., Parker, M.G., Sumpter, J.P., 1995. A variety of environmentally persistent chemicals, including some phthalate plasticizers, are weakly estrogenic. Environ Health Perspect. 103(6), 582-587.

Joint FAO/WHO Expert Committee on Food Additives (JECFA),, 2000. Toxicological evaluation of certain veterinary drug residues in food: estradiol-17ß, progesterone, and testosterone. WHO food additives series 43. World Health Organization, Geneva. http://www.inchem.org/documents/jecfa/jecmono/v43jec05.htm [Accessed 29/10/2017).

Kelce, W.R., Stone, C.R., Laws, S.C., Gray, L.E., Kemppainen, J.A., Wilson, E.M., 1995. Persistent DDT metabolite $\mathrm{p}, \mathrm{p}^{\prime}-\mathrm{DDE}$ is a potent androgen receptor antagonist. Nature 375(6532), 581-585.

Kelce, W.R., Wilson, E.M., 1997. Environmental antiandrogens: developmental effects, molecular mechanisms, and clinical implications. J Mol Med. 75(3), 198-207. 
Klein-Hitpass, L., Ryffel, G.U., Heitlinger, E. and Cato, A.C., 1988. A 13 bp palindrome is a functional estrogen responsive element and interacts specifically with estrogen receptor. Nucleic Acids Res. 16(2), 647-663.

Kowalska, K., Habrowska-Górczyńska, D.E., Piastowska-Ciesielska, A.W., 2016. Zearalenone as an endocrine disruptor in humans. Environ Toxicol Pharmacol. 48, 141-149.

Kuiper, G.G., Lemmen, J.G., Carlsson, B.O., Corton, J.C., Safe, S.H., Van Der Saag, P.T., Van Der Burg, B., Gustafsson, J.A., 1998. Interaction of estrogenic chemicals and phytoestrogens with estrogen receptor $\beta$. Endocrinology 139(10), 4252-4263.

Legler, J., van den Brink, C.E., Brouwer, A., Murk, A.J., van der Saag, P.T., Vethaak, A.D., van der Burg, B., 1999. Development of a stably transfected estrogen receptor-mediated luciferase reporter gene assay in the human T47D breast cancer cell line. Toxicol Sci. 48(1), $55-66$.

Li, J., Li, N., Ma, M., Giesy, J.P., Wang, Z., 2008. In vitro profiling of the endocrine disrupting potency of organochlorine pesticides. Toxicol lett. 183(1-3), 65-71.

Longnecker, M.P., Klebanoff, M.A., Brock, J.W., Zhou, H., Gray, K.A., Needham, L.L.,Wilcox, A.J., 2002. Maternal serum level of 1, 1-dichloro-2, 2-bis (p-chlorophenyl) ethylene and risk of cryptorchidism, hypospadias, and polythelia among male offspring. Am J Epidemiol. 155, 313-322.

Massart, F., Meucci, V., Saggese, G., Soldani, G., 2008. High growth rate of girls with precocious puberty exposed to oestrogenic mycotoxins. J Pediatr. 152, 690-695.

Metzler, M., Pfeiffer, E., Hildebrand, A., 2010. Zearalenone and its metabolites as endocrine disrupting chemicals. World Mycotoxin J. 3(4), 385-401.

Minervini, F., Dell'Aquila, M. E., 2008. Zearalenone and Reproductive Function in Farm Animals. Int J Mol Sci. 9, 2570-2584.

Molina-Molina, J.M., Real, M., Jimenez-Diaz, I., Belhassen, H., Hedhili, A., Torné, P., Fernández, M.F., Olea, N., 2014. Assessment of estrogenic and anti-androgenic activities of the mycotoxin zearalenone and its metabolites using in vitro receptor-specific bioassays. Food Chem Toxicol. 74, 233-239.

Mosselman, S., Polman, J. and Dijkema, R., 1996. ER $\beta$ : identification and characterization of a novel human estrogen receptor. FEBS lett. 392(1), 49-53.

Mueller, S.O., Simon, S., Chae, K., Metzler, M. and Korach, K.S., 2004. Phytoestrogens and their human metabolites show distinct agonistic and antagonistic properties on estrogen receptor $\alpha(\mathrm{ER} \alpha)$ and ER $\beta$ in human cells. Toxicol Sci. 80(1), 14-25.

Ndossi, D.G., Frizzell, C., Tremoen, N.H., Fæste, C.K., Verhaegen, S., Dahl, E., Eriksen, G.S., Sørlie, M., Connolly, L., Ropstad, E., 2012. An in vitro investigation of endocrine disrupting effects of trichothecenes deoxynivalenol (DON), T-2 and HT-2 toxins. Toxicol lett. 214(3), 268-278. 
Pillay, D., Chuturgoon, A.A., Nevines, E., Manickum, T., Deppe, W., Dutton, M.F., 2002. The quantitative analysis of zearalenone and its derivatives in plasma of patients with breast and cervical cancer. Clin Chem Lab Med. 40(9), 946-951.

Pillon, A., Boussioux, A.M., Escande, A., Aït-Aïssa, S., Gomez, E., Fenet, H., Ruff, M., Moras, D., Vignon, F., Duchesne, M.J., Casellas, C., 2005. Binding of estrogenic compounds to recombinant estrogen receptor- $\alpha$ : application to environmental analysis. Environ Health Perspect. 113(3), 278-284.

Rodrigues, I., Naehrer, K., 2012. A three-year survey on the worldwide occurrence of mycotoxins in feedstuffs and feed. Toxins 4(9), 663-675.

Romero-González, R., Frenich, A.G., Vidal, J.M., Prestes, O.D., Grio, S.L., 2011. Simultaneous determination of pesticides, biopesticides and mycotoxins in organic products applying a quick, easy, cheap, effective, rugged and safe extraction procedure and ultra-high performance liquid chromatography-tandem mass spectrometry. J Chromatogr A. 1218(11), $1477-1485$.

Shephard, G. S., Burger, H-S, Gambacorta, L., Gong, Y. Y., Krska, R., Rheeder, J. P., Solfrizzo, M., Srey, C., Sulyok, M., Visconti, A., Warth, B., van der Westhuizen, L., 2013. Multiple mycotoxin exposure ddetermined by urinary biomarkers in rural subsistence farmers in the former Transkei, South Africa. Food Chem Toxicol. 62, 217-225.

Shier, W.T., Shier, A.C., Xie, W., Mirocha, C.J., 2001. Structure-activity relationships for human estrogenic activity in zearalenone mycotoxins. Toxicon 39(9), 1435-1438.

Sonneveld, E., Jansen, H.J., Riteco, J.A., Brouwer, A., van der Burg, B., 2005. Development of androgen-and estrogen-responsive bioassays, members of a panel of human cell line-based highly selective steroid-responsive bioassays. Toxicol Sci. 83(1), 136-148.

Sotoca Covaleda, A.M., Van den Berg, H., Vervoort, J., Van der Saag, P., Ström, A., Gustafsson, J.Å., Rietjens, I. and Murk, A.J., 2008. Influence of cellular ER $\alpha / E R \beta$ ratio on the ER $\alpha$-agonist induced proliferation of human T47D breast cancer cells. Toxicol Sci. 105(2), 303-311.

Stypuła-Trębas, S., Minta, M., Radko, L., Żmudzki, J., 2016. Oestrogenic and (anti) androgenic activity of zearalenone and its metabolites in two in vitro yeast bioassays. World Mycotoxin J. 9(2), 247-255.

Tatay, E., Espín, S., García-Fernández, A.J., Ruiz, M.J., 2018. Estrogenic activity of zearalenone, $\alpha$-zearalenol and $\beta$-zearalenol assessed using the E-screen assay in MCF-7 cells. Toxicol Mech Methods. 28(4), 239-242.

Vejdovszky, K., Hahn, K., Braun, D., Warth, B., Marko, D., 2017a. Synergistic estrogenic effects of Fusarium and Alternaria mycotoxins in vitro. Arch Toxicol. 91(3), 1447-1460. 
Vejdovszky, K., Schmidt, V., Warth, B., Marko, D., 2017b. Combinatory estrogenic effects between the isoflavone genistein and the mycotoxins zearalenone and alternariol in vitro. Mol Nutr Food Res. 61(3), 1600526.

Wang, S., Aarts, J.M., Evers, N.M., Peijnenburg, A.A., Rietjens, I.M., Bovee, T.F., 2012. Proliferation assays for estrogenicity testing with high predictive value for the in vivo uterotrophic effect. J Steroid Biochem Mol Biol. 128(3-5), 98-106.

Wang, S., Rijk, J.C., Besselink, H.T., Houtman, R., Peijnenburg, A.A., Brouwer, A., Rietjens, I.M., Bovee, T.F., 2014a. Extending an in vitro panel for estrogenicity testing: the added value of bioassays for measuring antiandrogenic activities and effects on steroidogenesis. Toxicol Sci. 141(1), 78-89.

Wang, S., Aarts, J.M., Haan, L.H., Argyriou, D., Peijnenburg, A.A., Rietjens, I.M., Bovee, T.F., 2014b. Towards an integrated in vitro strategy for estrogenicity testing. J Appl Toxicol. 34(9), 1031-1040.

Warth, B., Parich, A., Atehnkeng, J., Bandyopadhyay, R., Schuhmacher, R., Sulyok, M., Krska, R., 2012. Quantitation of mycotoxins in food and feed from Burkina Faso and Mozambique using a modern LC-MS/MS multitoxin method. J Agric Food Chem. 60(36), 9352-9363.

Warth, B., Sulyok, M., Krska, R., 2013. LC-MS/MS-based multibiomarker approaches for the assessment of human exposure to mycotoxins. Anal Bioanal Chem. 405(17), 5687-5695.

Weber, F., Freudinger, R., Schwerdt, G. and Gekle, M., 2005. A rapid screening method to test apoptotic synergisms of ochratoxin A with other nephrotoxic substances. Toxicol In Vitro. 19(1), 135-143.

Wielogórska, E., Elliott, C.T., Danaher, M., Connolly, L., 2015. Endocrine disruptor activity of multiple environmental food chain contaminants. Toxicol In Vitro. 29(1), 211-220.

Willemsen, P., Scippo, M.L., Kausel, G., Figueroa, J., Maghuin-Rogister, G., Martial, J.A., Muller, M., 2004. Use of reporter cell lines for detection of endocrine-disrupter activity. Anal Bioanal Chem. 378(3), 655-663.

Wilson, V.S., Bobseine, K. and Gray Jr, L.E., 2004. Development and characterization of a cell line that stably expresses an estrogen-responsive luciferase reporter for the detection of estrogen receptor agonist and antagonists. Toxicol Sci. 81(1), 69-77. 


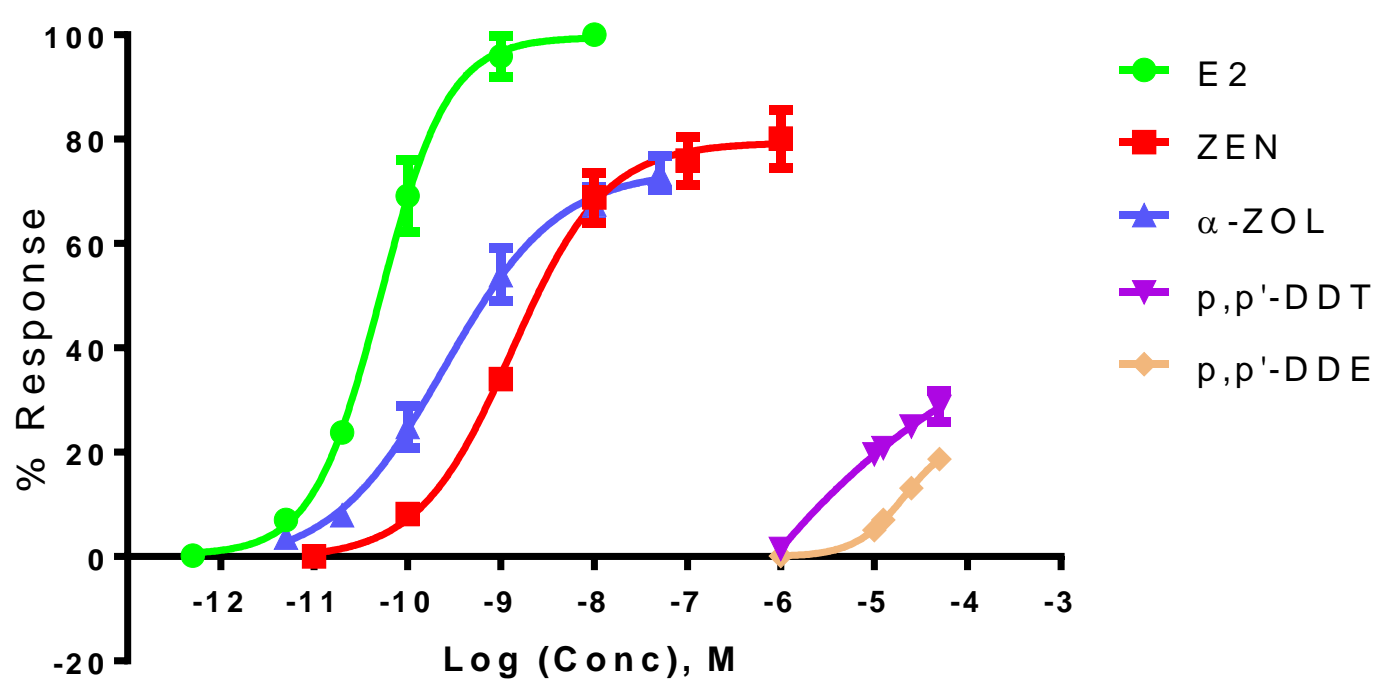

Fig. 1: Dose response curve of the transcriptional response elicited by $17 \beta$-oestradiol $\left(\mathrm{E}_{2}\right)$, zearalenone (ZEN), alpha-zearalenol ( $\alpha$-ZOL), 1,1,1-trichloro-2,2-bis(p-chlorophenyl) ethane ( $p, p^{\prime}$-DDT), and 1,1-dichloro-2,2-bis(p-chlorophenyl) ethylene ( $p, p^{\prime}$-DDE) with MMV-Luc reporter gene cell line. Test substances were assayed in triplicate in three independent experiments. Error bars represent standard deviation from three biological replicates. Results are expressed as percentage of maximal induction of $\mathrm{E}_{2}(100 \% ; 10 \mathrm{nM})$. 

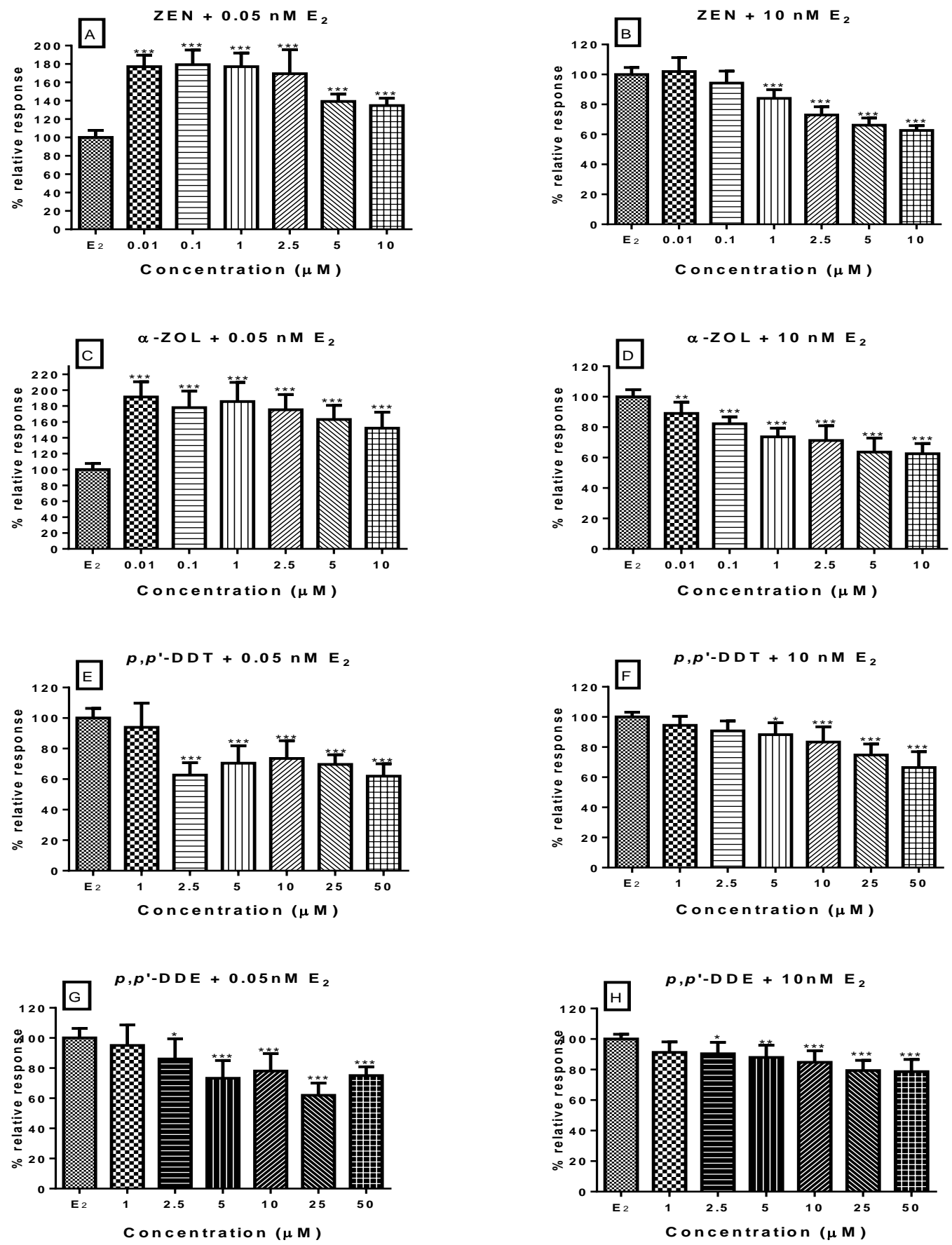

Fig. 2. Transcriptional response induced when increasing concentrations of single mycotoxins and persistent organochloride pesticides were co-exposed with either $0.05 \mathrm{nM}$ or $10 \mathrm{nM}$ of $\mathrm{E}_{2}$. Test substances were assayed in triplicate, in at least two independent experiments. Error bars represent standard deviation from at least two biological replicates. Results are expressed as percentage of maximal induction of $\mathrm{E}_{2}(0.05 \mathrm{nM}$ or $10 \mathrm{nM}) .{ }^{*} \mathrm{p} \leq 0.05,{ }^{* *} \mathrm{p} \leq 0.01,{ }^{* * *} \mathrm{p} \leq 0.001$ and $* * * * \mathrm{p} \leq 0.0001$ represents significant effects. 

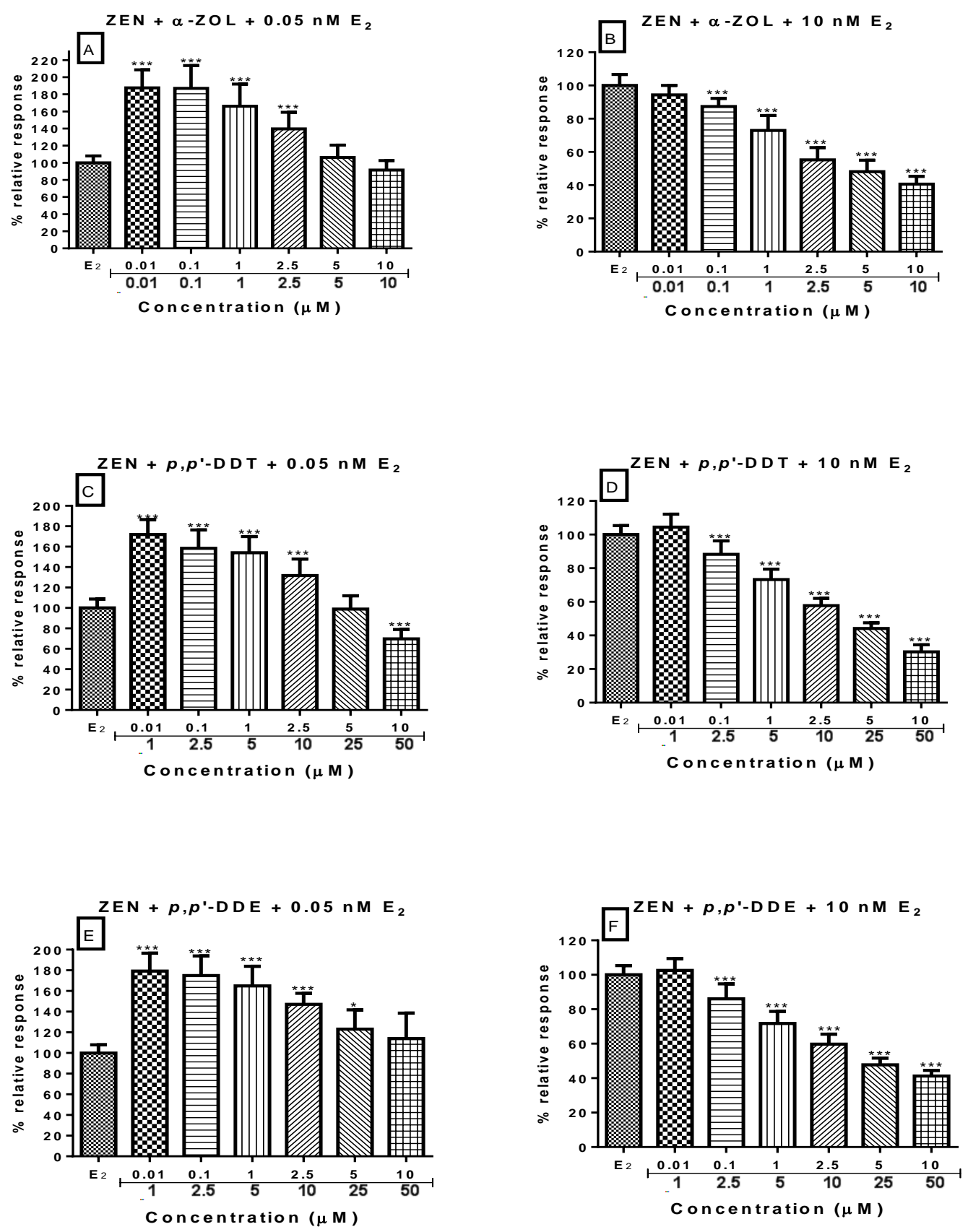

Fig. 3. Transcriptional response induced when increasing concentrations of binary mixtures of mycotoxins and persistent organochloride pesticides were co-exposed with either $0.05 \mathrm{nM}$ or $10 \mathrm{nM}$ of $E_{2}$. Test substances were assayed in triplicate, in at least two independent experiments. Error bars represent standard deviation from at least two biological replicates. Results are expressed as percentage of maximal induction of $\mathrm{E}_{2}(0.05 \mathrm{nM}$ or $10 \mathrm{nM}) .{ }^{*} \mathrm{p} \leq 0.05, * * \mathrm{p} \leq 0.01, * * * \mathrm{p} \leq 0.001$ and $* * * * \mathrm{p}$ $\leq 0.0001$ represents significant effects. 

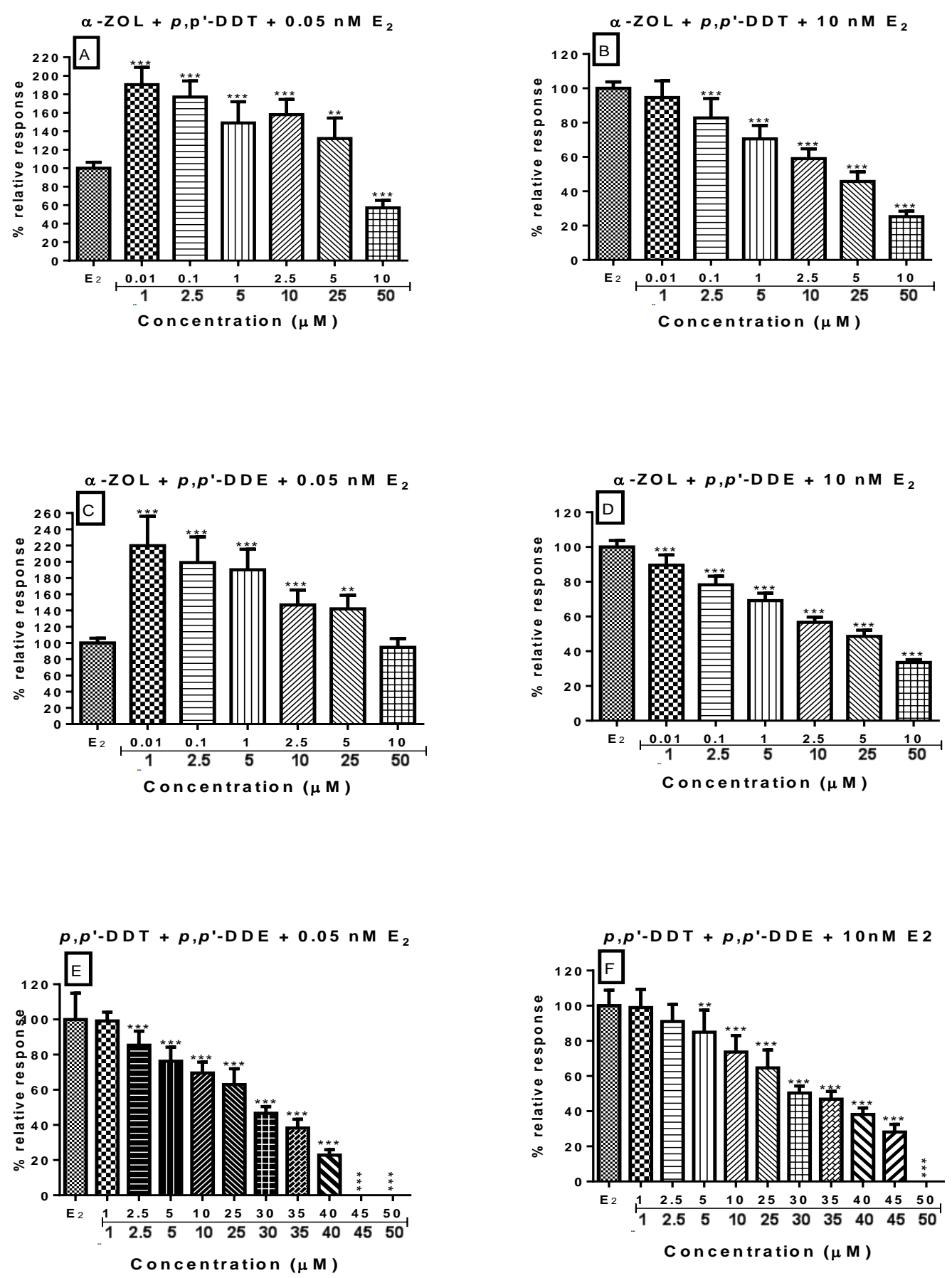

Fig. 4. Transcriptional response induced when increasing concentrations of binary mixtures of $\alpha$-ZOL and persistent organochloride pesticides ( $p, p^{\prime}$-DDT and $p, p^{\prime}-$ DDE) were co-exposed with either $0.05 \mathrm{nM}$ or $10 \mathrm{nM}$ of $E_{2}$. Test substances were assayed in triplicate, in at least two independent experiments. Error bars represent standard deviation from at least two biological replicates. Results are expressed as percentage of maximal induction of $\mathrm{E}_{2}(0.05 \mathrm{nM}$ or $10 \mathrm{nM}) .{ }^{*} \mathrm{p} \leq 0.05, * * \mathrm{p} \leq 0.01$, $* * * \mathrm{p} \leq 0.001$ and $* * * * \mathrm{p} \leq 0.0001$ represents significant effects. 
Table 1: The $\mathrm{EC}_{50}$ and maximal ER transcriptional response of the tested mycotoxins and pesticides

\begin{tabular}{|c|c|c|c|c|c|}
\hline & $\mathbf{E}_{2}$ & ZEN & $\alpha-Z O L$ & $p, p^{\prime}$-DDT & $p, p^{\prime}-\mathrm{DDE}$ \\
\hline $\mathrm{EC}_{50}$ & $\begin{array}{c}5.30 \times 10^{-11} \pm 1.17 \times 10^{-11} \mathrm{M} \\
(0.053 \pm 0.012 \mathrm{nM})\end{array}$ & $\begin{array}{c}1.32 \times 10^{-9} \pm 9.56 \times 10^{-11} \mathrm{M} \\
(1.32 \pm 0.0956 \mathrm{nM})\end{array}$ & $\begin{array}{c}2.70 \times 10^{-10} \pm 1.21 \times 10^{-10} \mathrm{M} \\
(0.27 \pm 0.121 \mathrm{nM})\end{array}$ & N/A & N/A \\
\hline $\mathbf{R}^{2}$ & 0.9952 & 0.9905 & 0.9888 & 0.9845 & 0.9895 \\
\hline $\begin{array}{l}\text { Maximal } \\
\text { induction } \\
(\%)\end{array}$ & $100 \pm 0.00$ & $80.11 \pm 5.58$ & $73.45 \pm 3.25$ & $28.70 \pm 2.97$ & $18.65 \pm 1.77$ \\
\hline
\end{tabular}




\section{SUPPLEMENTARY INFORMATION}

The effect of single and mixtures of mycotoxins and persistent organochloride pesticides on oestrogen receptor transcriptional activation using in vitro reporter gene assays

Ukpai A. Eze ${ }^{\text {a, b, c, } \psi}$, John D. Huntriss ${ }^{\mathrm{c}}$, Michael N. Routledge ${ }^{\mathrm{d}}$, and Yun Yun Gong a, e, * and Lisa Connolly ${ }^{\mathrm{f}}$

Food and Chemical Toxicology

Supplementary file 1. Cell viability of MMV-Luc cell line exposed to different chemical treatments 

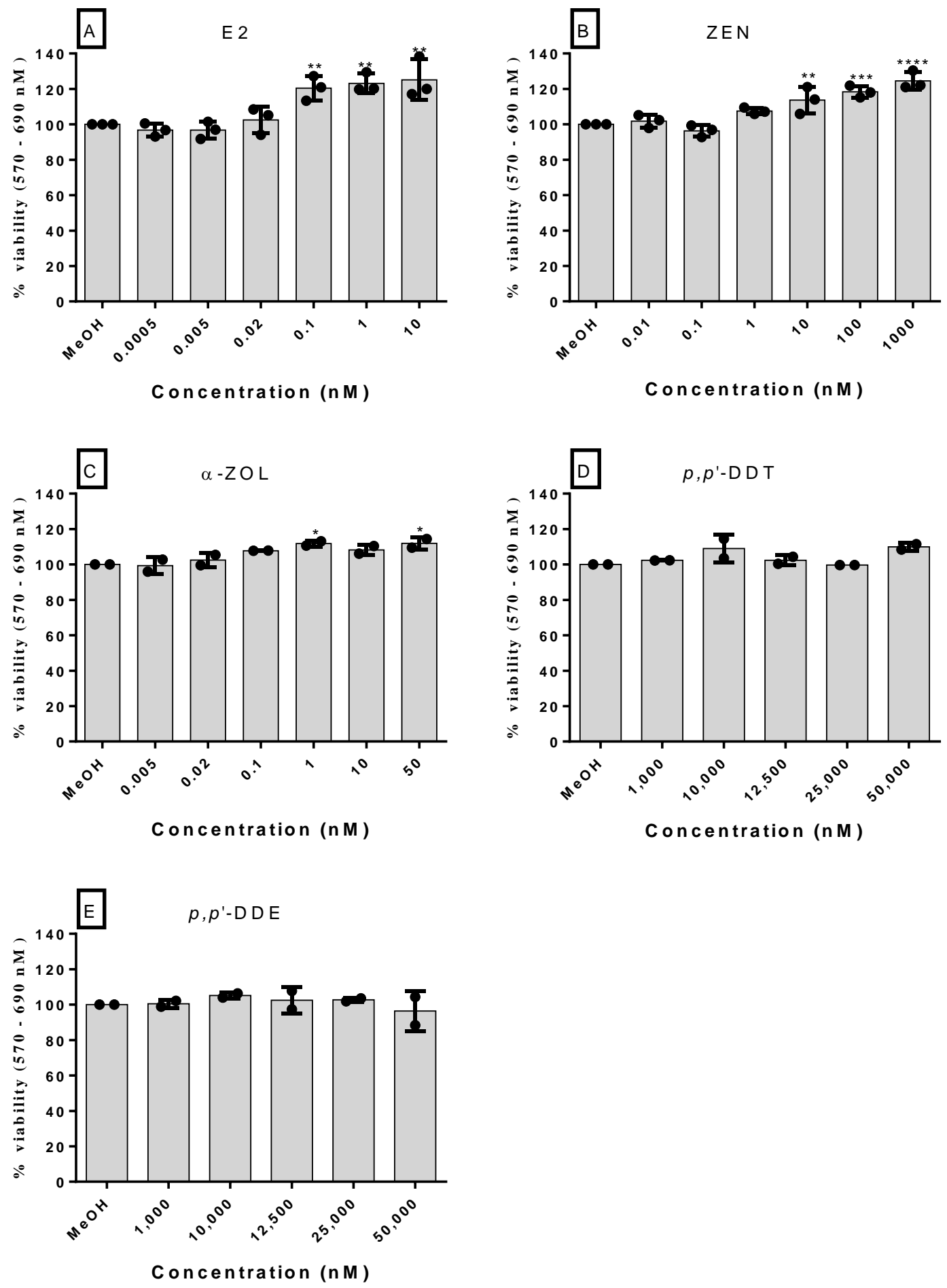

Fig. S1.1: Cell viability of MMV-Luc reporter gene cell line exposed to $17 \beta$-oestradiol $\left(\mathrm{E}_{2}\right)$, zearalenone (ZEN), alpha-zearalenol ( $\alpha$-ZOL), 1,1,1-trichloro-2,2-bis(p-chlorophenyl) ethane ( $p, p^{\prime}$-DDT), and 1,1-dichloro-2,2-bis(p-chlorophenyl) ethylene ( $p, p^{\prime}$-DDE). Test substances were assayed in triplicate in at least two independent experiments. Data were analysed with one-way ANOVA and corrected for multiple comparison using the Dunnett's test method. Error 
bars represent standard deviation of at least two biological replicates. Results are expressed as percentage of methanol $(\mathrm{MeOH})$ control. ${ }^{*} \mathrm{p} \leq 0.05,{ }^{*} \mathrm{p} \leq 0.01, * * * \mathrm{p} \leq 0.001$ and ${ }^{* * * *} \mathrm{p} \leq$ 0.0001 represents significant effects.
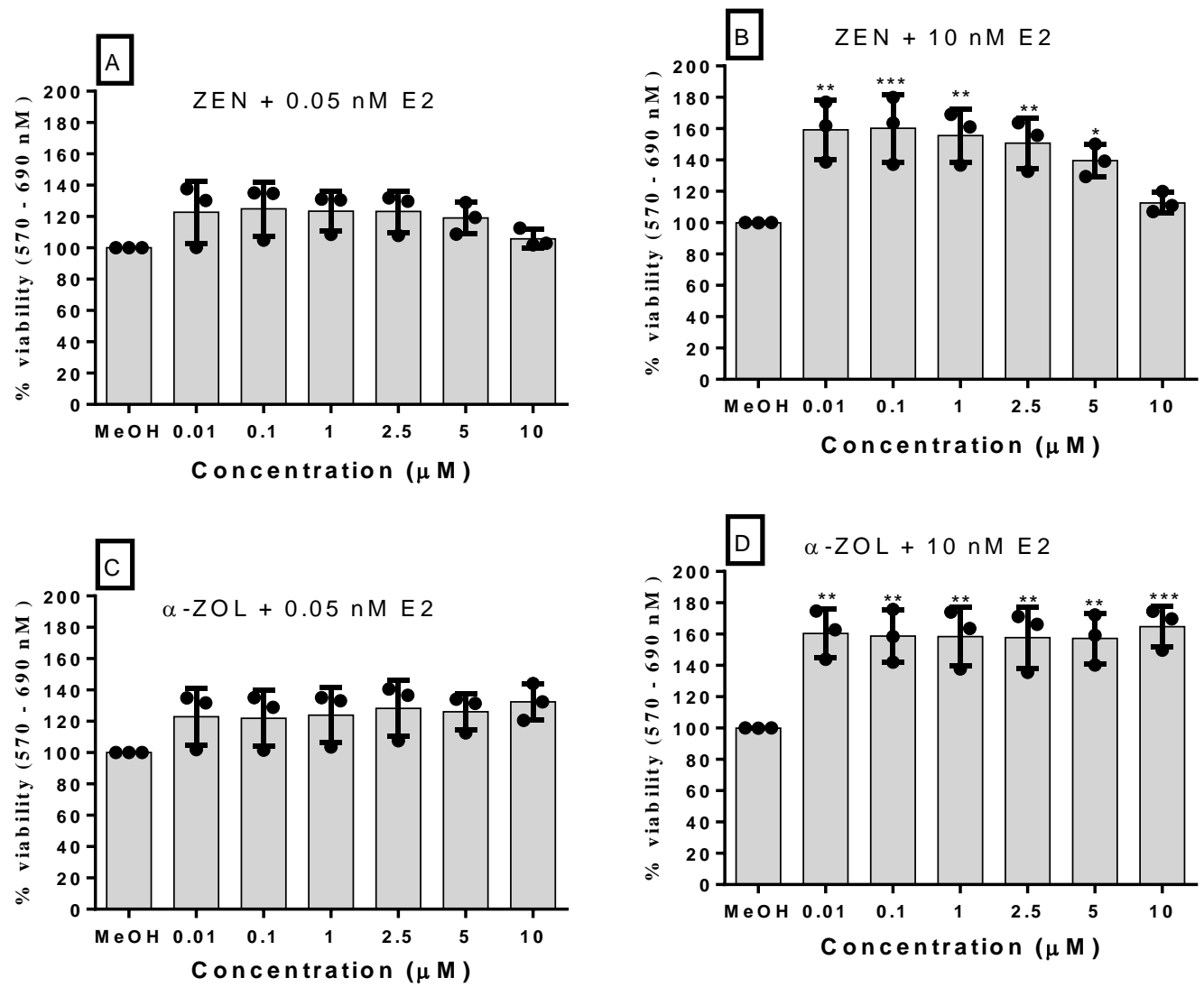

Fig. S1.2: Cell viability of MMV-Luc reporter gene cell line exposed to either zearalenone (ZEN) or alpha-zearalenol $(\alpha-Z O L)$ in combination with $0.05 \mathrm{nM}$ or $10 \mathrm{nM}$ of $17 \beta$-oestradiol $\left(E_{2}\right)$. Test substances were assayed in triplicate in three independent experiments. Data were analysed with one-way ANOVA and corrected for multiple comparison using the Dunnett's test method. Error bars represent standard deviation of three biological replicates. Results are expressed as percentage of methanol $(\mathrm{MeOH})$ control. ${ }^{*} \mathrm{p} \leq 0.05, * * \mathrm{p} \leq 0.01, * * * \mathrm{p} \leq 0.001$ and $* * * * \mathrm{p} \leq 0.0001$ represents significant effects. 

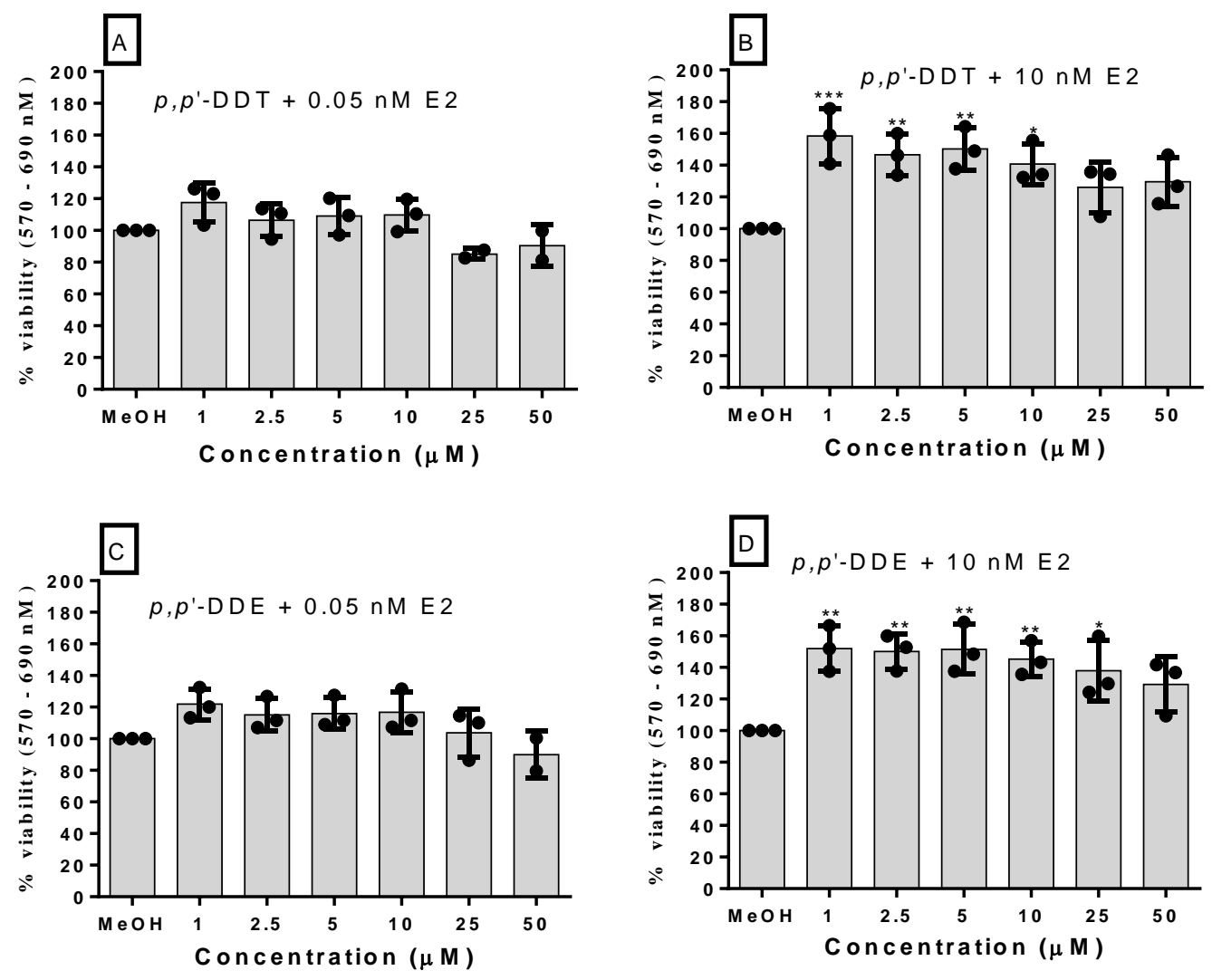

Fig. S1.3: Cell viability of MMV-Luc reporter gene cell line exposed to either 1,1,1-trichloro2,2-bis(p-chlorophenyl) ethane ( $p, p^{\prime}$-DDT), and 1,1-dichloro-2,2-bis(p-chlorophenyl) ethylene $\left(p, p^{\prime}\right.$-DDE) in combination with $0.05 \mathrm{nM}$ or $10 \mathrm{nM}$ of $17 \beta$-oestradiol $\left(\mathrm{E}_{2}\right)$. Test substances were assayed in triplicate in at least two independent experiments. Data were analysed with one-way ANOVA and corrected for multiple comparison using the Dunnett's test method. Error bars represent standard deviation of at least two biological replicates. Results are expressed as percentage of methanol $(\mathrm{MeOH})$ control. $* \mathrm{p} \leq 0.05, * * \mathrm{p} \leq 0.01, * * * \mathrm{p} \leq 0.001$ and $* * * * \mathrm{p} \leq$ 0.0001 represents significant effects. 

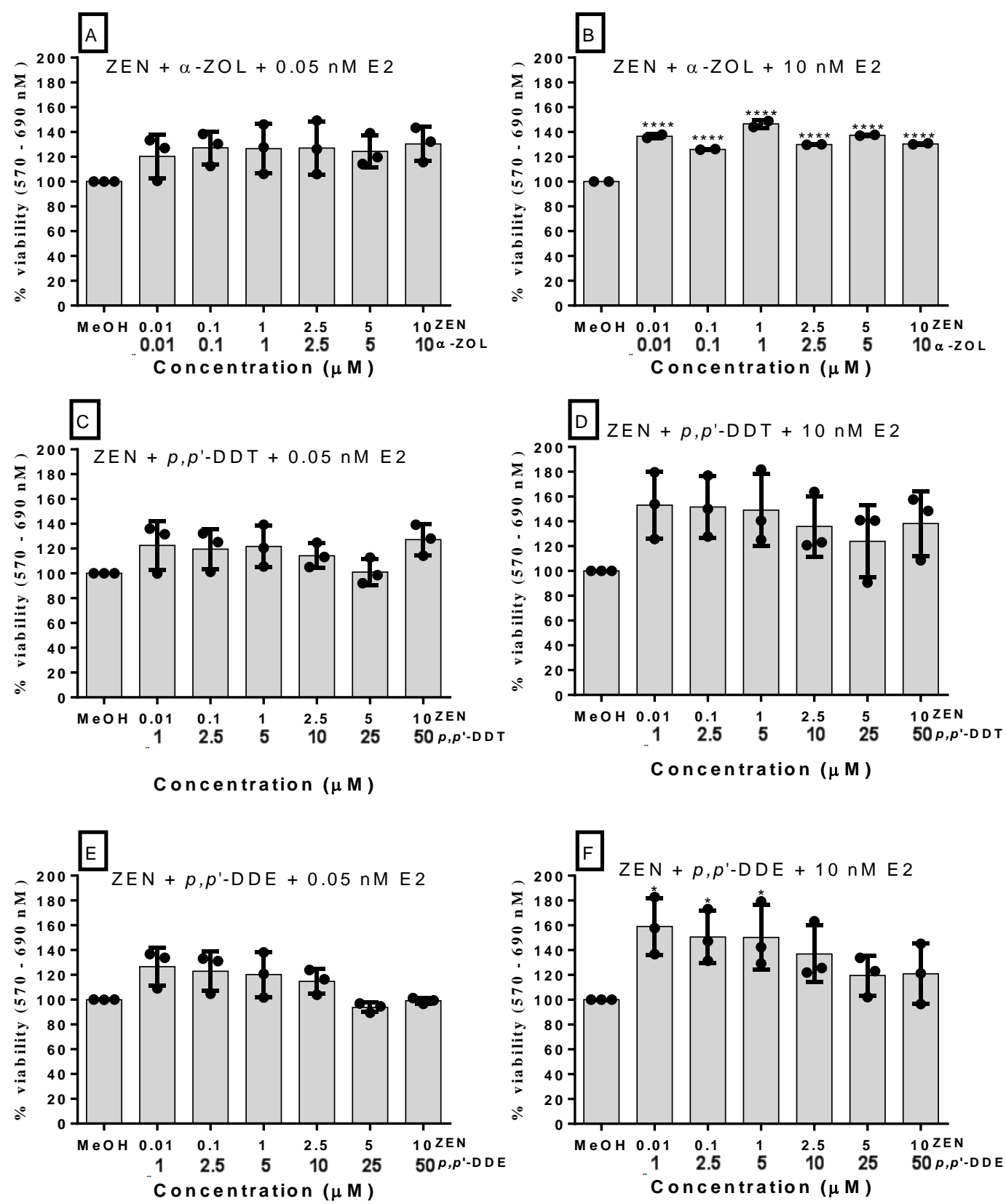

Fig. S1.4: Cell viability of MMV-Luc reporter gene cell line exposed to binary combination of zearalenone (ZEN) with either alpha-zearalenol ( $\alpha$-ZOL), 1,1,1-trichloro-2,2-bis(pchlorophenyl) ethane ( $p, p^{\prime}$-DDT), or 1,1-dichloro-2,2-bis(p-chlorophenyl) ethylene ( $p, p^{\prime}$ $\mathrm{DDE}$ ) in conjunction with $0.05 \mathrm{nM}$ or $10 \mathrm{nM}$ of $17 \beta$-oestradiol $\left(\mathrm{E}_{2}\right)$. Test substances were assayed in triplicate in at least two independent experiments. Data were analysed with one-way ANOVA and corrected for multiple comparison using the Dunnett's test method. Error bars represent standard deviation of at least two biological replicates. Results are expressed as percentage of maximal induction of $\mathrm{E}_{2}(0.05 \mathrm{nM}$ or $10 \mathrm{nM})$. Results are expressed as percentage 
of methanol $(\mathrm{MeOH})$ control. $* \mathrm{p} \leq 0.05, * * \mathrm{p} \leq 0.01, * * * \mathrm{p} \leq 0.001$ and $* * * * \mathrm{p} \leq 0.0001$ represents significant effects.
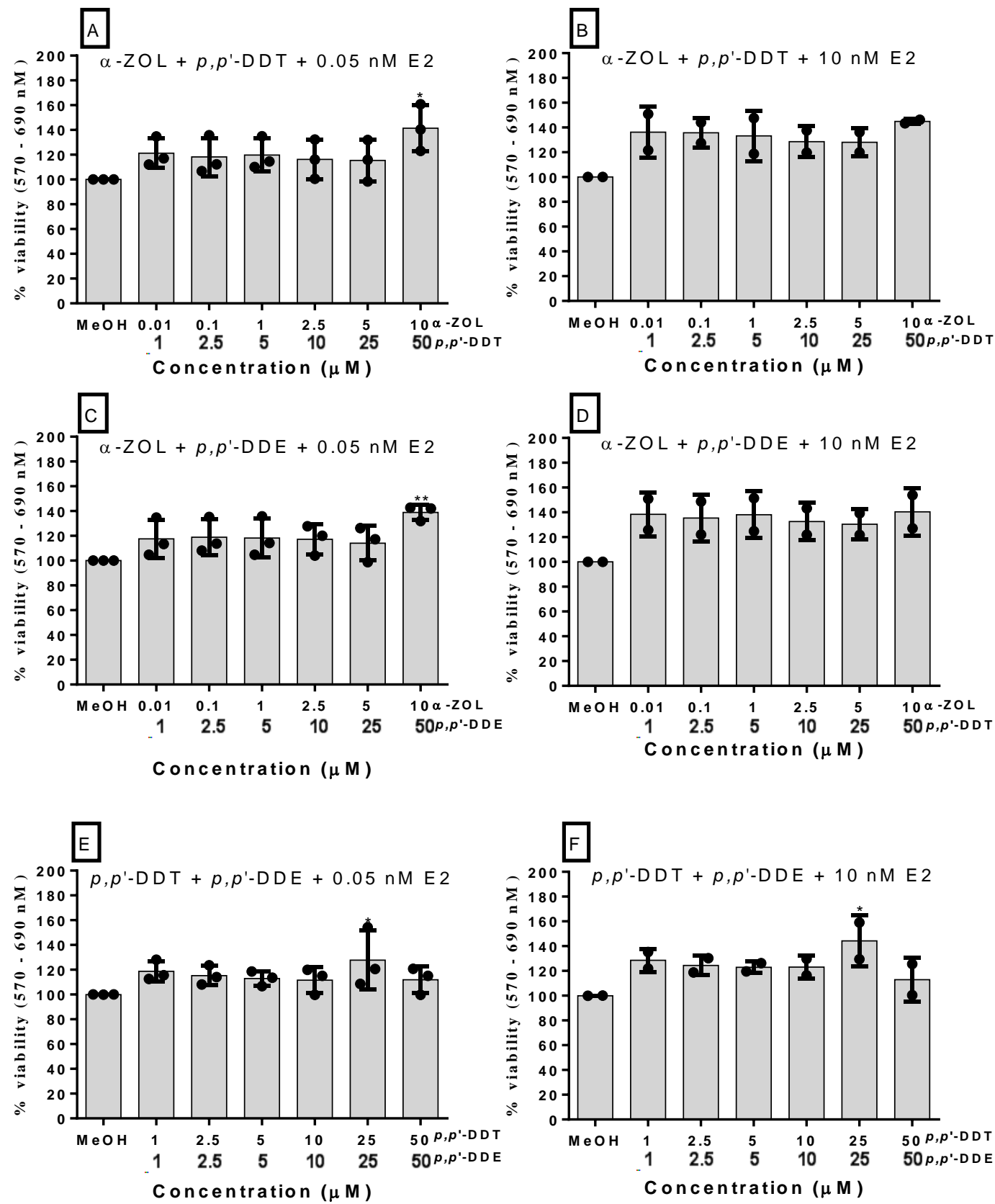

Fig. S1.5: Cell viability of MMV-Luc reporter gene cell line exposed to binary combination of $\alpha$-ZOL with either $p, p^{\prime}$-DDT (A \& B), or $p, p^{\prime}$-DDE (C \& D), and co-exposure of $p, p^{\prime}$-DDT and $p, p^{\prime}-\mathrm{DDE}(\mathrm{E} \& \mathrm{~F})$ in conjunction with $0.05 \mathrm{nM}$ or $10 \mathrm{nM}$ of $17 \beta$-oestradiol $\left(\mathrm{E}_{2}\right)$. Test substances were assayed in triplicate in at least two independent experiments. Data were analysed with one-way ANOVA and corrected for multiple comparison using the Dunnett's test method. Error bars represent standard deviation of at least two biological replicates. Results are expressed as 
percentage of maximal induction of $\mathrm{E}_{2}(0.05 \mathrm{nM}$ or $10 \mathrm{nM})$. Results are expressed as percentage of methanol $(\mathrm{MeOH})$ control. ${ }^{*} \mathrm{p} \leq 0.05, * * \mathrm{p} \leq 0.01, * * * \mathrm{p} \leq 0.001$ and $* * * * \mathrm{p} \leq$ 0.0001 represents significant effects. 


\section{SUPPLEMENTARY INFORMATION}

The effect of single and mixtures of mycotoxins and persistent organochloride pesticides on oestrogen receptor transcriptional activation using in vitro reporter gene assays

Ukpai A. Eze ${ }^{\text {a, b, c, } \psi}$, John D. Huntriss ${ }^{\mathrm{c}}$, Michael N. Routledge ${ }^{\mathrm{d}}$, and Yun Yun Gong a, e, * and Lisa Connolly ${ }^{\mathrm{f}}$

Food and Chemical Toxicology

Supplementary file 2. The interactive effects of combined mycotoxins and/or persistent organochloride pesticides on $\mathrm{E}_{2}$-mediated ER transcriptional activation 

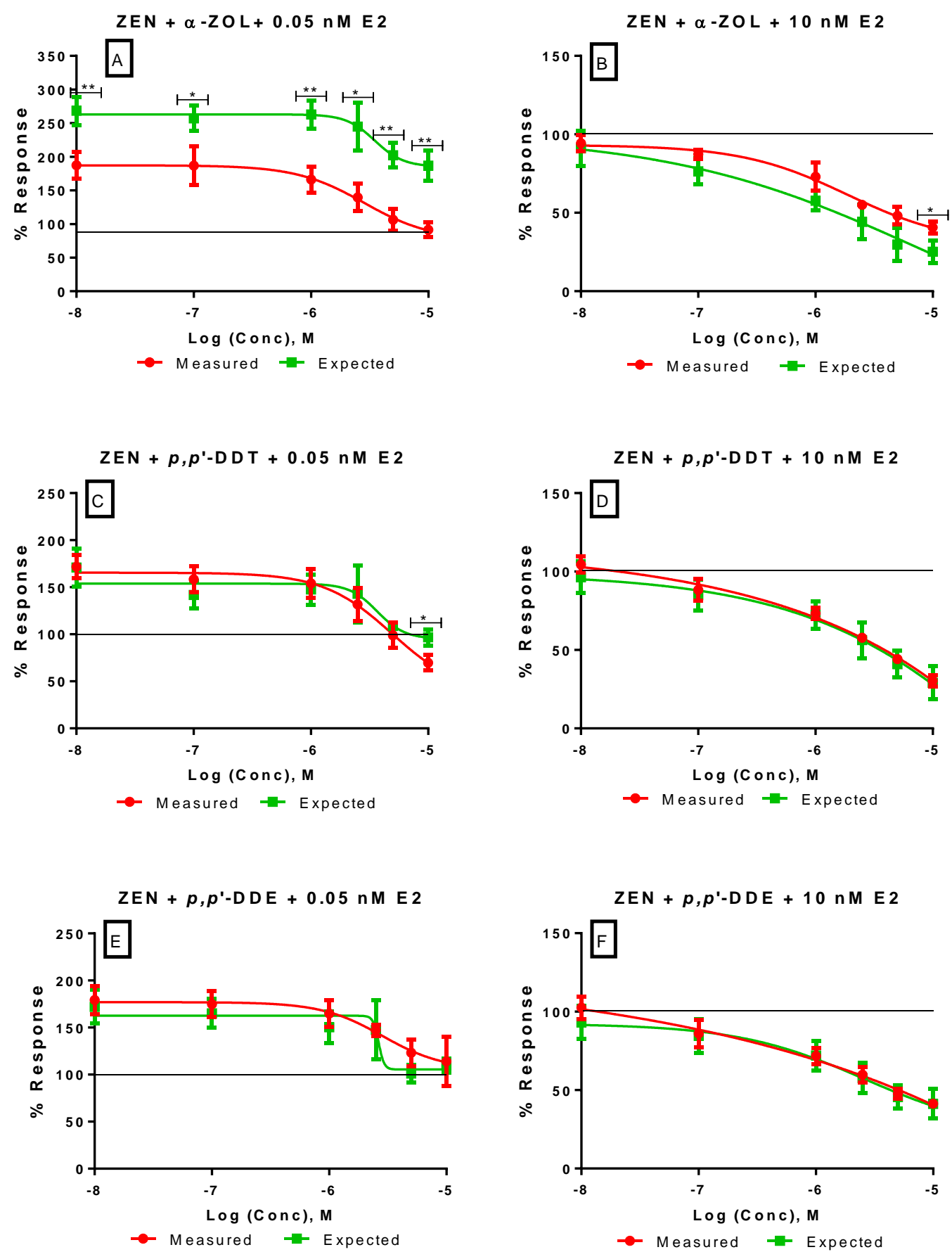

Fig. S2.1: Measured and expected ER transcriptional response induced when increasing concentrations of binary mixtures of mycotoxins and persistent organochloride pesticides were co-exposed with either $0.05 \mathrm{nM}$ or $10 \mathrm{nM}$ of $E_{2}$. Test substances were assayed in triplicate, in three independent experiments. Data were analysed with multiple t-test and corrected for multiple comparison using the Holm-Š́ídák test method. Error bars represent standard deviation 
of three biological replicates. Results are expressed as percentage of maximal induction of $E_{2}$ $(0.05 \mathrm{nM}$ or $10 \mathrm{nM}) .{ }^{*} \mathrm{p} \leq 0.05, * * \mathrm{p} \leq 0.01, * * * \mathrm{p} \leq 0.001$ and $* * * * \mathrm{p} \leq 0.0001$ represents significant effects.
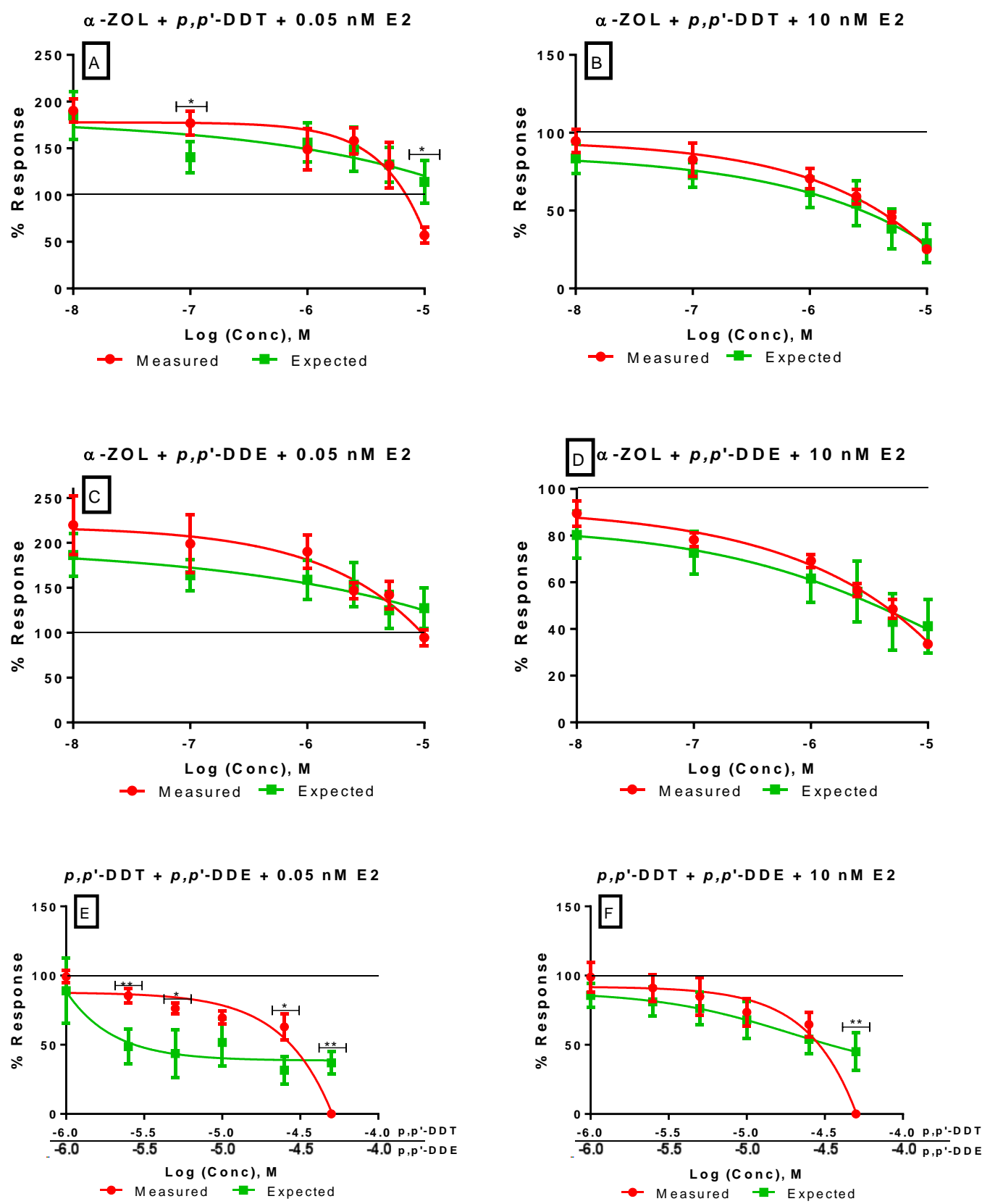

Fig. S2.2: Measured and expected ER transcriptional response induced when increasing concentrations of binary mixtures of $\alpha-\mathrm{ZOL}$ and persistent organochloride pesticides $\left(p, p^{\prime}\right.$ - 
DDT and $p, p^{\prime}$-DDE) were co-exposed with either $0.05 \mathrm{nM}$ or $10 \mathrm{nM}$ of $\mathrm{E}_{2}$. Test substances were assayed in triplicate in three independent experiments. Data were analysed with multiple t-test and corrected for multiple comparison using the Holm-Šídák test method. Error bars represent standard deviation of three biological replicates. Results are expressed as percentage of maximal induction of $\mathrm{E}_{2}(0.05 \mathrm{nM}$ or $10 \mathrm{nM}) . * \mathrm{p} \leq 0.05, * * \mathrm{p} \leq 0.01, * * * \mathrm{p} \leq 0.001$ and $* * * * \mathrm{p}$ $\leq 0.0001$ represents significant effects. 